\title{
Políticas públicas coordenadas e presidencialismo de coalizão: o caso do PROMESO
}

\author{
JoÃo MENDES da ROCHA Neto \\ Universidade de Brasília / Programa de Pós-graduação em AdMinistração, Brasília - DF, BrasiL
}

DJALMA FrEIRE BORGES

Universidade federal do Rio Grande do Norte / Programa de Pós-graduação em Administração, Natal - RN, Brasil

\begin{abstract}
Resumo
As políticas públicas têm sido estudadas com base em diferentes aspectos teóricos. No entanto, ainda persiste uma lacuna nas questões relacionadas à integração de ações das agências governamentais. Essas dimensões, quando estudadas, pouco se aproximam da perspectiva dos impactos decorrentes da arquitetura do presidencialismo de coalizão sobre as políticas públicas, que, no caso brasileiro, corrobora sua fragmentação e competição entre agências governamentais que deveriam atuar de forma integrada. Este artigo objetiva identificar onde esse problema se manifesta e o ponto de inflexão entre o discurso da ação coordenada e a implementação que evidencia o contrário. Para demonstrar como isso ocorre foi escolhido o Programa de Promoção da Sustentabilidade de Espaços Sub-Regionais (Promeso), que tem agendas compartilhadas como um de seus importantes instrumentos. A elaboração da pesquisa demandou uma revisão teórica que se debruçou sobre a arquitetura institucional do presidencialismo de coalizão e dos partidos políticos, além de adotar, na pesquisa empírica, a base de dados da Secretaria de Orçamento Federal (SOF/MPOG) e do Sistema Integrado de Administração Financeira do Governo (Siafi/MF), que permitiram espacializar a distribuição dos recursos públicos segundo as lógicas partidárias e regionalizadas, e consultar documentos oficiais do Ministério da Integração Nacional (MI) que caracterizam o programa objeto deste estudo. A pesquisa comprovou que o presidencialismo de coalizão afeta diretamente as políticas públicas, evidenciando um caráter competitivo entre as agências do governo federal, em razão das lógicas particularizadas, determinadas pelos dirigentes dessas instituições.
\end{abstract}

Palavras-chave: Políticas públicas. Competição. Presidencialismo de coalizão. Partidos políticos. PROMESO.

\section{Coordinated public policies and coalition presidentialism: the case of PROMESO}

\section{Abstract}

Public policies have been studied with various theoretical aspects as a basis. However, there is still a gap on issues related to the interconnection of actions taken by government agencies. These dimensions, when addressed, do not get close to the perspective of impacts derived from the architecture of coalition presidentialism on public policies, which, in the Brazilian case, corroborates its fragmentation and competition between government agencies that should work in an interconnected way. This article aims at identifying where this problem is expressed and the inflection point between the discourse of coordinated action and an implementation showing the opposite. To demonstrate how this occurs, we chose the Brazilian Program for Promoting Sustainability in Sub-Regional Spaces (PROMESO), which has shared agendas as one of its significant instruments. Research construction required a theoretical review that focuses on the institutional architecture of coalition presidentialism and political parties, besides adopting, in empirical investigation, the database of the Brazilian Federal Budget Department (SOF/MPOG) and the Brazilian Interconnected System of Government Financial Administration (SIAFI/MF), which enabled us to spatialize the distribution of public resources according to a party and region-based rationale, and refer to official documents from the Brazilian Ministry of National Integration (MI) that characterize the program addressed in this study. The research proved that coalition presidentialism directly affects public policies, highlighting a competitive nature between the federal government agencies, due to particular rationales, determined by directors at these institutions.

Keywords: Public policies. Competition. Coalition presidentialism. Political parties. PROMESO.

\section{Políticas públicas coordinadas y presidencialismo de coalición: el caso de PROMESO}

\section{Resumen}

Las políticas públicas se han estudiado con diversos aspectos teóricos como base. Sin embargo, aún existe una laguna en cuestiones relacionadas con la integración de acciones de agencias gubernamentales. Estas dimensiones, cuando se estudian, no se acercan a la perspectiva de impactos derivados de la arquitectura del presidencialismo de coalición sobre las políticas públicas, que, en el caso brasileño, corrobora su fragmentación y competencia entre agencias gubernamentales que deberían operar de manera interconectada. Este artículo tiene como objetivo identificar donde este problema se expresa y el punto de inflexión entre el discurso de la acción coordinada y la implementación que muestra lo contrario. Para demostrar cómo se produce esto, elegimos el Programa de Promoción de la Sostenibilidad de Espacios SubRegionales de Brasil (PROMESO), que ha compartido agendas como uno de sus instrumentos importantes. La construcción de la investigación ha demandado una revisión teórica que se centró en la arquitectura institucional del presidencialismo de coalición y los partidos políticos, además de adoptar, en la investigación empírica, la base de datos de la Secretaria de Presupuesto Federal de Brasil (SOF/MPOG) y el Sistema Integrado de Administración Financiera del Gobierno (SIAFI/MF), que permitieron espacializar la distribución de los recursos públicos según las lógicas partidistas y regionalizadas, y consultar documentos oficiales del Ministerio de la Integración Nacional de Brasil (MI) que caracterizan el programa que constituye el objeto de este estudio. La investigación demostró que el presidencialismo de coalición afecta directamente a las políticas públicas, lo que muestra una naturaleza competitiva entre las agencias del gobierno federal, debido a lógicas particulares, determinadas por los directores de estas instituciones.

Palabras clave: Políticas públicas. Competencia. Presidencialismo de coalición. Partidos políticos. PROMESO. 


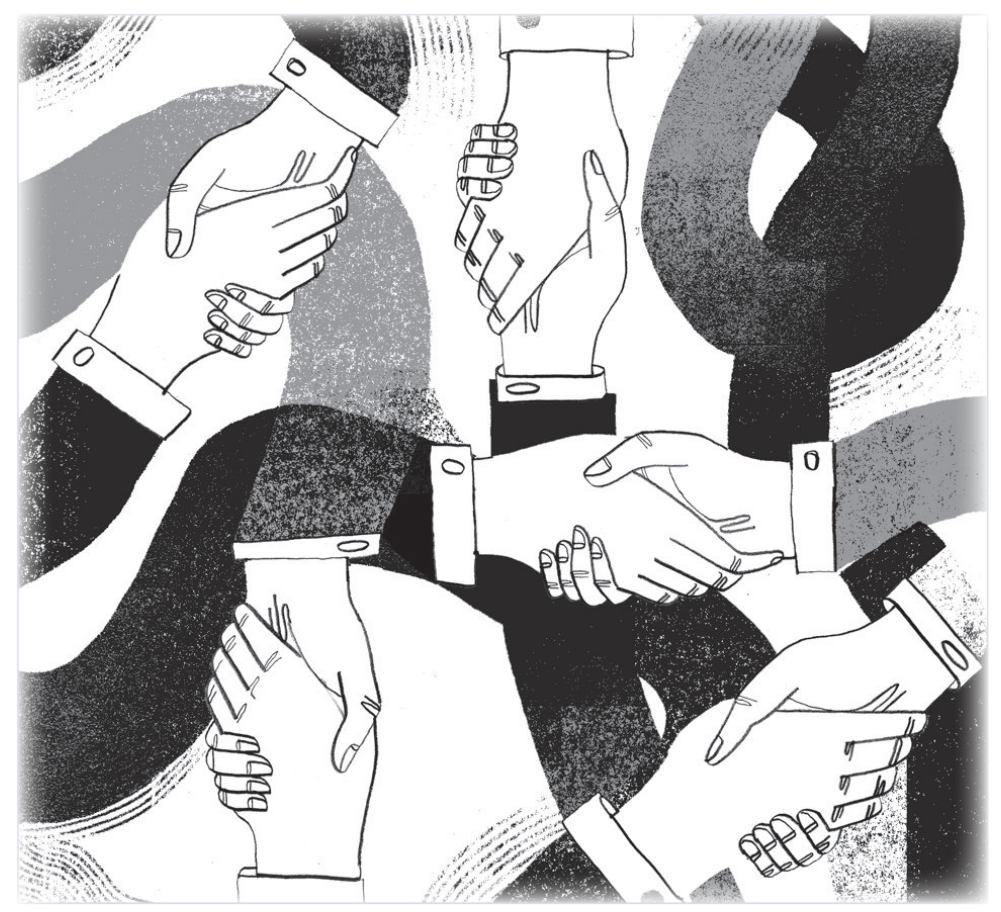

\section{INTRODUÇÃO}

Muitos são os temas discutidos nos últimos anos relativos à administração pública, como reforma do Estado, federalismo, descentralização, crise fiscal, governabilidade, governança, coordenação, fragmentação, intersetorialidade, horizontalidades e verticalidades, entre outras. Nesse sentido, vale refletir sobre uma dimensão que muitas vezes não é explicitada nos estudos: o caráter competitivo dessas ações diante do modelo presidencialista de coalizão existente no Brasil. Em tal modelo, as legendas agregam-se em busca da composição de uma base política com a finalidade máxima de eleger os cargos majoritários - no caso do governo federal, o presidente da República - e, assim, fazerem parte de seu gabinete ministerial, ocupando o primeiro e o segundo escalões dos postos dirigentes. Isso, inclusive, se tornará relevante nos arranjos de ato res (políticos ou não) que tornam viáveis os programas de governo dos presidentes e podem lhes garantir um ambiente favorável no que se refere à governabilidade.

Apesar de chegarem juntos ao poder, alguns desses partidos têm orientações ideológicas muito heterogêneas, bem como lógicas particulares de operação marcadas por suas relações e compromissos com os grupos de interesse e com porções do território nacional que ocupam espaços diferentes em suas agendas, constituindo verdadeiras redes.

Trata-se de um aspecto importante no entendimento dessa relação complexa e contraditória entre "parceiros" em um governo que se compartimenta em projetos partidários, regionais e setoriais. Tal fragmentação reflete-se nas políticas públicas, que, ao contrário de se caracterizarem pela coordenação, passam a competir entre si, principalmente naquelas onde há agendas intersetoriais e responsabilidades compartilhadas. Isso reforça o caráter fragmentário e competitivo entre as políticas públicas e as instituições responsáveis por sua implementação, mesmo quando há previsão de cooperação, por força do tema e dos instrumentos que as desenham.

\footnotetext{
* Fonte da imagem: Gazeta do Povo. Disponível em: http://www.gazetadopovo.com.br/opiniao/colunistas/friedmann-wendpap/colapso-politico-8q2dk 500 5031cvx7wapeyb9o8. Acesso em 25 maio 2016.
} 
Tal quadro aponta para uma compreensão mais profunda das políticas públicas, evitando-se o lugar-comum das análises que se têm centrado apenas nas questões objetivas orientadoras de tais instrumentos de ação governamental. De fato, essa perspectiva coloca em debate algo além das objetividades, recuperando aspectos subjetivos que influenciam todo o curso da política pública, como: culturas organizacionais, conflitos e disputas entre grupos de interesse e partidos políticos.

O debate propicia questões centrais para este artigo: a primeira é o fato de se reconhecer que o Estado brasileiro tem sido fortemente influenciado, na formação de sua agenda de políticas públicas, pelos grupos de poder que ocupam mais espaço nas decisões e, consequentemente, no atendimento de suas demandas. Isso se evidencia nos governos com diferentes matizes ideológicos, quando alguns desses grupos adquirem maior visibilidade e têm suas demandas atendidas de forma mais sistematizada por um conjunto de políticas públicas.

Um segundo ponto é a histórica cultura das disputas entre instituições, forjadas pela divisão do poder entre os vários partidos que sustentam o governo. Isso é reforçado quando são tratados temas de grade alcance que conferem visibilidade no cenário político e na sociedade, sendo, portanto, capazes de garantir posições privilegiadas a quem deles se ocupa.

É inegável que as políticas públicas, dependendo do que tratam, podem ser objeto de maior consenso e, assim, se revelam menos conflituosas. Evidentemente, nem sempre é possível essa pacificação de interesses, mas, ao se decidir pelo desenho de uma política pública, busca-se ao menos, em tese, a superação das divergências, o que tem sido bastante dificultado por causa dos pontos já elencados. Nesse sentido, este artigo procura, de forma breve, propor para debate esse instigante e delicado tema que expressa, nas políticas públicas, a complexidade do modelo presidencialista de coalizão brasileiro, em que há uma crescente competição entre os partidos da base de apoio do governo, bem como uma "irrigação" de recursos, favorecendo determinadas frações do território nacional, de acordo com o dirigente ministerial e suas vinculações partidárias.

É importante esclarecer as razões que levaram à opção pelos anos 2005 e 2006. Em primeiro lugar, só em tempos recentes, mais precisamente no governo de Luiz Inácio Lula da Silva, foi retomado o tema do desenvolvimento regional, expresso, inclusive, nos dois Planos Plurianuais de suas gestões; em segundo, foi durante seu primeiro mandato que ações compartiIhadas para as Mesorregiões Diferenciadas foram sistematizadas e, portanto, postas em execução por intermédio da Câmara de Políticas de Integração Nacional e Desenvolvimento Regional, adotando uma perspectiva transversal, com a elaboração de Agendas de Compromissos; em terceiro, durante o mesmo governo intensificou-se a agenda de combate às desigualdades, quer sociais, quer regionais, com a ampliação de programas e instituições relacionadas ao tema e, por último, durante seu primeiro mandato, a base de apoio à governabilidade tornou-se bastante heterogênea, o que acabou por acentuar o problema da competição e da distribuição dos recursos segundo lógicas partidárias e regionais. Ressalte-se que essa não é uma questão associada a este ou àquele governante, mas a uma arquitetura institucional marcada por complexidade, heterogeneidade e corporativismos arraigados na estrutura do Estado brasileiro.

O artigo teve como ponto de partida uma revisão bibliográfica da ciência política, com ênfase no modelo presidencialista brasileiro, e da intersetorialidade na administração pública que serviram de lastro teórico. De forma complementar, fez-se uma pesquisa documental das normas e publicações oficiais que explicitam o desenho do Programa de Promoção da Sustentabilidade de Espaços Sub-Regionais (Promeso). Adicionalmente, foram usadas as bases de dados do Portal da Transparência (CGU/PR), do Siafi/Ministério da Fazenda e da Secretaria de Orçamento Federal/MPOG, para verificar o volume dos repasses de recursos de caráter voluntário (convênios). Foram feitas também consultas ao Tribunal Superior Eleitoral (TSE), com vistas a identificar a composição dos quadros do Legislativo federal e dos governadores dos estados no período de tempo objeto da pesquisa. Esse conjunto de informações sistematizadas e posteriormente analisadas possibilitou as inferências apresentadas neste artigo.

De início, discutiu-se a relação político-partidária existente no sistema presidencialista brasileiro e seus reflexos nas políticas públicas que demandam algum nível de coordenação na esfera federal. Em seguida, há um breve debate sobre o panorama político-partidário e sobre as formas de essas legendas operarem no sistema social brasileiro. No tópico seguinte, analisa-se como essas legendas partidárias se relacionam entre si e como participam dos gabinetes ministeriais. Depois dessa digressão, o artigo detém-se na pesquisa, demonstrando o caráter competitivo e pouco colaborativo existente nas políticas públicas que demandam coordenação, com ênfase no Promeso. Por fim, são feitas algumas considerações sobre o modelo presidencialista e seus impactos nas políticas públicas intersetoriais, a fim de provocar o debate sobre os liames dessa competição em face do presidencialismo de coalizão. 


\section{POLÍTICAS PÚBLICAS NO SISTEMA PRESIDENCIALISTA BRASILEIRO}

O modelo presidencialista do país foi caracterizado como de "coalizão" por Sérgio Abranches (1988), que apontou um traço concreto da institucionalidade brasileira, em que se combinam a proporcionalidade, o multipartidarismo e o "presidencialismo imperial". Nesse modelo, o detentor do cargo majoritário organizaria o Poder Executivo baseado em alianças partidárias.

Concorda-se aqui com as características apontadas pelo autor, reconhecendo que há, sim, por parte do presidente, maior poder de estruturar agendas e decidir prioridades do governo, o que necessariamente não significa que aquelas definições tenham efetividade, uma vez que muitas dependem do estabelecimento de uma relação "amistosa" com os partidos políticos representados no parlamento federal, bem como com outros quadros dirigentes, a exemplo dos governadores.

Percebe-se, assim, a existência de forças políticas e legendas partidárias que podem ser indutoras dessa composição e que estão além das vontades e das decisões do presidente, o que fica bastante evidente nas palavras de Meneguello (1998, p. 150) ao comentar "[...] a lógica subjacente à definição das bases governamentais é uma lógica partidário-parlamentar [...], a natureza partidária das equipes de governo mostra que os partidos são agentes centrais do funcionamento dos governos".

Embora caracterizado pela concentração de poder "nas mãos" do presidente, sobretudo para controle do Executivo, o modelo brasileiro de gestão pública ainda é permeado e partilhado com quadros oriundos das legendas partidárias que ocupam as casas legislativas, os quais, mediante suas forças, indicam correligionários para compor o governo, sobretudo nos escalões mais altos.

É muito comum que essas indicações políticas sejam feitas em troca do apoio dos grupos de interesse que oferecem sustentação a seus mandatos. Nesse aspecto, vale registrar a reflexão de Limongi (2006, p. 36) quando diz: “[...] a coalizão que pode apoiar o presidente é marcada pela heterogeneidade de sua composição [...]; relações fisiológicas e clientelísticas pautariam as relações entre os eleitores e seus representantes e, como consequência, as relações entre o Executivo e o Legislativo".

Há, portanto, uma considerável relação com as eleições proporcionais, uma vez que estas definem o espaço de cada um dos partidos nas casas legislativas e sua importância para a governabilidade do mandatário principal. Essa participação vai lhes conferir maiores espaços nas indicações no Poder Executivo e, portanto, maior possibilidade de interferência nas políticas públicas, conforme salienta Machado (2010, p. 228): “[...] no presidencialismo, mais assentos legislativos [...] significam força partidária para a consideração do presidente depois da eleição". Assim, no Brasil, a distribuição de cargos está diretamente associada ao número de assentos que cada uma das legendas integrantes da coalizão tem no Congresso Nacional e, portanto, a seu poder de tornar viáveis os interesses do governo nas disputas que se estabelecem durante os mandatos.

Há que se destacar que esse agrupamento de partidos políticos não é novo, tampouco particular ao Brasil. No entanto, adquire aqui contornos complexos em face da amplitude e da heterogeneidade das legendas partidárias, as quais vão ao poder nas eleições majoritárias, manifestada nas municipalidades, nos estados ou no governo federal, com prefeitos, governadores e o presidente, respectivamente. Sobre tal questão, Machado (2010, p. 346) se pronuncia: "[...] a ampla utilização de coligações partidárias nas disputas eleitorais é uma das características marcantes da vida política brasileira".

Tal fato tornou-se emblemático no país, sobretudo nos períodos de governos democráticos, desenhando políticas com base em um amálgama de atores e agentes pautados pela orientação do chefe de governo e também de grupos de interesses mais próximos das estruturas do poder, desenhando um cenário bastante complexo.

Desde meados da década de 1980, estabeleceu-se, por força constitucional, o multipartidarismo, que, ao longo dos últimos anos, resultou na crescente fragmentação das legendas e do surgimento de novas agremiações partidárias. Esse arranjo de governo com vários partidos se tornou um recurso indispensável para quem deseja ser eleito aos cargos majoritários, ampliando-se sobremaneira nos últimos mandatos presidenciais.

$\mathrm{O}$ instrumento das coligações leva alguns partidos a se alinhar em diferentes momentos. Isso resulta, depois do processo eleitoral e da declaração dos vencedores, em uma rede para governar, da qual participam legendas ideologicamente mais próximas à vitoriosa e outras que nem sempre com essa estiveram afinadas.

Pode ocorrer também que, depois do encerramento do processo eleitorial, para garantir um governo sem grandes sobressaltos, algumas legendas "vendam" seu apoio aos vencedores que as "compram" em troca de cargos no alto escalão. Assim, é 
necessário entender que uma proposta de programa de governo pode ser modificada, em graus distintos, em razão de seus apoiadores partidários. Nesse sentido, segundo Krause e Godoi (2010, p. 42) pontuam:

[...] a dinâmica da busca de aliança, a partir do princípio geral da economia de esforços e maximização de ganhos, é parte do pressuposto de que os partidos políticos avaliam o ambiente em que estão inseridos e procuram se posicionar com a intenção de angariar o maior número possível de votos e vantagens. Neste sentido, a ação coligacionista seria elaborada por um princípio baseado eminentemente em uma racionalidade instrumental. Coligação seria um instrumento disponível para abarcar um maior eleitorado, mas, também, uma interessante ferramenta para ter influência e acesso à maquina governamental e aproximação com núcleos decisórios após os pleitos.

Portanto, essa arquitetura que se faz no momento da disputa também se transfere como forma de "compromisso" quando da composição dos gabinetes ministeriais. É o momento em que as "faturas" são cobradas e o apoio oferecido tem um preço, que se traduz na distribuição dos cargos, sobretudo daqueles de maior prestígio e visibilidade na agenda governamental e/ ou daqueles que têm recursos e instrumentos para "fazer política com as políticas", conforme se discute a seguir.

\section{PARTIDOS E POLÍTICOS: O DESVIRTUAMENTO DO SISTEMA EM NOME DA REPRESENTAÇÃO DE INTERESSES}

Quando vistos isoladamente os grupos de interesse pouco representam no processo decisório governamental. No entanto, como destaca Marsh (1997), esse processo na verdade envolve três atores: burocracia, governo e grupos de interesse. Ou seja, o que é denominado "triângulo de ferro" pela literatura norte-americana. O que vai garantir destaque a esse triângulo é o grau de coesão dos grupos privados e sua capacidade de articulação com os outros dois atores.

Marsh (1997) considera essas relações cruciais ao entendimento da formação das agendas de políticas em democracias estáveis e destaca o crescimento de grupos de interesse como algo inerente à evolução dos sistemas democráticos, em face da complexidade social e da consequente desagregação e fragmentação dos interesses individuais.

Ainda sobre o assunto, Kingdon (2007) destaca entre os atores governamentais importantes na formação da agenda o grupo denominado "administração central", que seria o chefe do Executivo que, no caso do Brasil, seria o presidente da República; o staff do gabinete executivo composto pelos ministros e, por último, os dirigentes e assessores nomeados de acordo com sua vinculação política ao chefe de governo, os quais ocuparão cargos dos escalões inferiores.

Kingdon (2007, p. 222) destaca também um aspecto esclarecedor da complexidade na formação da agenda, ao revelar que: "[...] o presidente e seus assessores mais próximos, por exemplo, têm nas suas agendas os itens mais importantes". Ferraz (2009, p. 425) complementa esse entendimento, apontando que: "[...] políticos eleitos para o Executivo ou em cargos de confiança têm seus próprios objetivos, propostas e agendas e tentam mobilizar o público para apoiar as decisões propostas".

Percebe-se um traço que une as relações políticas a fim de garantir governabilidade ao país: a intenção dos atores em permanecer nas estruturas de poder, se não pessoalmente, ao menos por meio das legendas partidárias, atendendo aos interesses corporativos que vão compor uma miríade de agendas pessoais, ideológicas, partidárias, setoriais e regionais. Ainda sobre esse corte dos interesses corporativos no campo da política partidária, Ferraz (2009, p. 429) pontua que: “[...] podem afetar as agendas de políticas públicas pelo contexto de suas plataformas, pelo impacto de sua liderança no âmbito do Legislativo e pela pressão que podem exercer sobre seus partidários, bem como pela defesa das ideologias que representam".

Essa breve discussão evidencia que os políticos eleitos ou que ocupam altos cargos têm seus próprios objetivos, propostas e agendas, defendendo pautas particulares, e tentam mobilizar os grupos no sentido de associá-los aos interesses partidários e, se possível, legitimar tais interesses como parte da agenda nacional.

Tais formas de operar revelam uma relação tensa e competitiva entre os indivíduos que atuam no cenário político do país e conduzem ao que Downs apud Limongi (2006, p. 27), denomina office seeking, quando fala da classe, entendendo que "[...] como presidentes e legisladores respondem a eleitorados diversos, segue que têm interesses distintos, isto é, que procurarão enviesar as políticas públicas para eleitorados diversos. Portanto, inevitavelmente, entrarão em conflito". 
Assim, as escolhas de política pública são a expressão verdadeira de valores que resultam na competição de diferentes perspectivas ou preferências. Legitimam-se, inclusive, grupos de interesse, ou parte deles, na esfera da política partidária, o que contribui para um cenário de disputa de poder com reflexos nas políticas públicas, sobretudo nas que não têm focos específicos e permitem, assim, uma diversidade de ações, atores e agências operando conjuntamente.

Tal situação corrobora a análise ora apresentada e aponta para uma dificuldade não de governabilidade, na esfera política, mas de levar a cabo o que foi decidido e determinado como agenda de governo, seja no projeto partidário vencedor, seja por iniciativa do chefe do Executivo.

As legendas que contribuem para essa governabilidade podem ser aquinhoadas com a oferta dos cargos no Executivo ou com outras formas de "premiar" partidos e políticos. Na esfera do Legislativo, é possível encontrar, sobre tal relação, a colaboração pertinente de Pereira e Mueller (apud IPEA, 2010, p. 98), que assim se posicionam:

O presidente da República recompensa os parlamentares que sistematicamente votam a favor dos projetos de interesse do governo autorizando a execução de suas emendas individuais e, ao mesmo tempo, pune os que não votam nesses projetos, simplesmente não executando as emendas propostas por eles [...]; [há] existência de forte motivação particularista entre os deputados com a total discricionariedade do Executivo na execução daquelas emendas [...] [o que] leva ao comportamento venal dos parlamentares [...], a importância desse padrão residiria menos no seu impacto negativo sobre as despesas do governo e mais no seu impacto positivo sobre a produção de políticas públicas, no sentido de garantir a governabilidade [...] tornando o atendimento das demandas clientelistas dos parlamentares um meio de o Executivo obter apoio legislativo para a aprovação da sua agenda de políticas públicas.

Portanto, verifica-se que, na operacionalização do sistema, os recursos materiais do Estado desempenham um importante papel. De fato, os partidos políticos que apoiam o governo têm acesso a privilégios por meio desses recursos, o que lhes confere prestígio e lhes abre a possibilidade de ampliar seus espaços no competitivo cenário eleitoral. Reis (1995) denomina tal processo "institucionalização do sistema partidário", caracterizado pela força das legendas. Um bom exemplo disso é o Partido do Movimento Democrático Brasileiro (PMDB), que está presente em todos os governos desde a retomada da democracia no país, independentemente da orientação ideológica do chefe do Executivo.

Os privilégios, além do favorecimento no acesso aos recursos, também redundam na criação de símbolos de prestígio para os principais interlocutores dessas redes, chamados por Nunes (1997) de "corretores", o que facilita seu relacionamento com os centros de poder e, em consequência, os coloca em posição de destaque diante dos grupos de interesse e de suas legendas partidárias. Tornam-se, portanto, sujeitos importantes e, por que não dizer, indispensáveis nesse relacionamento entre grupos da sociedade civil e governo, conseguindo ter boa penetração em todo o aparato estatal.

Muitas vezes esses personagens da política brasileira são acionados e alçados a postos ministeriais como forma de "retribuição" ao apoio recebido de corporações e de legendas partidárias no projeto de governo e na garantia da governabilidade. Souza apud Melo (1996, p. 67) dimensiona tal aspecto conceituando-o como "força eleitoral” e diz que: "[...] isso tem a ver com a articulação dos partidos com bases sociais e força institucional [...], como a influência de organizações partidárias no policy making governamental”. Assim, tem poder quem está no governo ou quem está com o governo.

Os autores aqui mencionados discutem questões relativas às políticas públicas e à formação da agenda e não deixam de tocar em um aspecto crucial do processo, o político, "[...] onde interesses e propostas são" colocados na "mesa" de negociações, "[...] definindo-se preferências que são adaptadas ao projeto político governamental" (KINGDON, 2007, p. 236, grifo nosso).

Tal fato vem despertando a atenção dos cientistas políticos nacionais que, desde a retomada da democracia, estudam as coligações e a diversidade de legendas que se aliam para alcançar a vitória e governar. Alguns desses estudos detêm-se na "coesão" ideológica dessas alianças e chegam mesmo a dizer que nos últimos anos estão cada vez menos homogêneas nos seus traços de união.

Carreirão e Nascimento (2010), que estudaram os partidos de diferentes matizes ideológicos que compunham a coalizão de apoio ao governo Lula, destacaram tal fato. Segundo os autores essa coalizão chega ao poder em face de uma série de aspectos, destacando-se a centralidade de sua proposta inovadora de governar com foco no social. Não se descuidou, no entanto, da aliança com forças políticas tradicionais que haviam sido muito criticadas e combatidas pelo então candidato, 
em eleições anteriores, quando ele não obteve êxito nas disputas para a presidência. As palavras de Peixoto (2010, p. 285) revelam tal fato: "[...] o comportamento do Partido dos Trabalhadores (PT), que já no comando da Presidência da Republica com Luiz Inácio Lula da Silva muda completamente suas estratégias de coligações e tende a diluir suas preferências por partidos de todo [o] espectro ideológico".

Sem pretender esgotar o assunto, amplo e muito complexo, a parte subsequente do artigo discute a contribuição dessa fragmentação partidária na competição entre políticas públicas.

\section{O CONTEXTO PARTIDÁRIO BRASILEIRO: CONTRIBUIÇÕES PARA O CARÁTER FRAGMENTÁRIO E COMPETITIVO DAS POLÍTICAS PÚBLICAS}

Como já destacado, desde meados da década de 1980 abriu-se, no Brasil, a possibilidade da criação de partidos políticos. Em um país recém-saído de governos militares e marcado por enorme passivo no diálogo entre o Estado e a sociedade, as demandas corporativas (e ao mesmo tempo fragmentadas) irromperam todas ao mesmo tempo, levando à ampliação das legendas que, à sua maneira, foram se incorporando à dimensão política institucionalizada.

Em um primeiro momento isso foi bastante salutar, uma vez que rompia com o bipartidarismo até então existente e permitia a pluralidade política e ideológica das legendas, fazendo com que a sociedade reconhecesse a complexidade do sistema partidário. No momento subsequente, essa grande quantidade de partidos começou a enfrentar dificuldades para se manter no cenário político nacional, tanto nas eleições majoritárias quanto nas proporcionais. Esse fato, ao contrário do que normalmente se poderia pensar, não se limitou aos partidos menores. Afetou fortemente as grandes legendas do país, que, para alcançarem os postos mais altos do Poder Executivo (presidência e governos estaduais), viram-se obrigadas a se aliar com outros partidos não só para vencerem eleições, mas, também, para garantirem a governabilidade em seus mandatos.

O embate entre as grandes legendas de expressão nacional, nos processos eleitorais dos últimos vinte anos, levou à formação de alianças e coligações bastante complexas nas suas posições ideológicas, porém vistas como necessárias para a garantia de "projetos de governo".

São elucidativas as palavras de Miguel e Machado apud Carreirão e Nascimento (2010, p. 105), ao comentarem um momento recente do cenário político nacional: "[...] quanto mais o PT se flexibilizou para constituir coligações das mais abrangentes possíveis, melhores foram seus resultados". Tal raciocínio complementa-se pela fala de Peixoto $(2010$, p. 284) ao se referir a outro importante protagonista da cena contemporânea da política brasileira: "[...] o PMDB é o principal parceiro de quase todos os partidos. Fato que pode ser explicado por ser o partido mais presente nos municípios brasileiros, assim como por gozar da estratégia de ser um partido de centro".

Em um país tão heterogêneo como o Brasil, um importante recurso de poder de um partido é a sua capilaridade e alcance territorial, que lhe permite não só exercer pressão em todos os níveis da Federação, como também participar de uma ampla rede de conexões com grupos de interesse diversificados. Essa capilaridade dos partidos, nas eleições majoritárias ou nas proporcionais, apresenta uma relação ao mesmo tempo lógica e complexa. Isso porque estar presente em muitos municipios possibilita manter consideráveis contigentes eleitorais sob sua liderança. Por outro lado, uma vez encerrada a eleição, essa conta é debitada ao líder político mais próximo que, por sua vez, a repassa aos níveis superiores de sua legenda (governadores, ministros, deputados estaduais e federais, senadores), o que reforça a dimensão da distribuição de recursos e favores com base em cortes geográficos.

Nesse sentido é importante retomar Abranches (1988, p. 22) que afirma: "A lógica da formação de coalizões tem, nitidamente, dois eixos: o partidário e o regional [...]. É isso que explica a recorrência das grandes coalizões, pois o cálculo relativo à base de sustentação política do governo não é apenas partidário-parlamentar, mas também regional".

Portanto, nos arranjos de coligação, há também um componente geográfico no atendimento às demandas da classe política, as quais se constituem como canais de interlocução da sociedade e de grupos de interesses localizados em determinadas partes do território que têm suas agendas particularizadas. $O$ acionamento dos políticos, nesses casos, se dá pela tentativa de agregar essas demandas às agendas de governo e fazer valer, mediante diferentes estratégias, suas vontades, tornando-as exequíveis. 
Tal multiplicidade de grupos de interesse reforça a prática da permuta de favores e perpetua uma relação que, para concretizar um projeto de governo, vale-se de "velhas/novas" práticas clientelistas favorecendo a corretagem, por parte do parlamento, dos interesses de alguns segmentos. Nesse sentido, a contribuição de Landé (1983, p. 436) é relevante, ao dizer que: "[...] as relações clientelísticas são consideradas como um meio do Estado - e das elites políticas em particular - para atenderem às demandas específicas de setores ou grupos sociais, integrando-os no sistema político e cooptando-os. A ideia de troca de benefícios públicos por votos e apoio político está fortemente presente nesses estudos".

Tal posição também encontra abrigo nas reflexões de Limongi (2006), quando argumenta que o critério partidário não é o bastante para sustentar politicamente o presidente e que o federalismo, com o poder dos governadores e de algumas municipalidades de maior expressão - além da complexidade da sociedade brasileira e de suas muitas corporações e grupos de interesse -, tornaram as coalizões imperiosas no momento da eleição ou quando da formação do governo, principalmente com vistas ao atendimento dos compromissos pactuados.

De tal forma, os grupos de poder, em especial a classe política, contribuem decisivamente para o caráter fragmentário das políticas públicas e a coordenação intersetorial se torna um obstáculo frequente a ser transposto no trato das agendas partilhadas, conforme será visto adiante.

\section{AGENDAS PARTILHADAS VERSUS AGENDAS PARTICULARES: TRAÇOS DA COMPETIÇÃO ENTRE AGÊNCIAS GOVERNAMENTAIS}

Muitos têm sidos os esforços e as contribuições teóricas para melhoria da governança. Destaque-se a discussão sobre "horizontalidade", definida por Bakvis e Juillet (2004, p. 17) como:

[...] a coordenação e gestão de um conjunto de atividades entre duas ou mais unidades organizacionais em esquemas em que as unidades em questão não exercem controle hierárquico sobre as outras e cujo objetivo é gerar resultados que não podem ser alcançados isoladamente por elas.

O fato é que essa busca por um melhor diálogo tem pautado os governos de diversos Estados nacionais em todo o mundo, independentemente de sua condição de desenvolvimento. É claro que em alguns desses isso adquire maior espaço no próprio Estado e nos debates da sociedade, que reclama por uma atuação mais eficiente.

Cabe destacar, ainda, que o esforço de coordenação necessariamente inclui a sensibilização para abordagens intersetorais nas políticas públicas, e, segundo, Inojosa (2001, p. 106):

Esta ação implica, então, na articulação dos diferentes setores que, em ação conjunta, tentarão, além de resolver os problemas da sociedade [...] O trabalho intersetorial supõe [...] o diálogo, o trabalho simultâneo entre os atores envolvidos [...] a busca por resultados integrados.

Adicionalmente, há mais dois conceitos de intersetorialidade: “Convergência de esforços de diferentes setores governamentais e não governamentais para produzir políticas integrais e integradas que ofereçam respostas as necessidades gerais (FERNANDEZ e MENDES apud GRAU, 2005, p. 2) e "Articulação de saberes e experiências no planejamento, realização e avaliação de ações com o objetivo de alcançar resultados integrados em situações complexas [...]" (JUNQUEIRA et al., apud GRAU, 2005, p. 2).

O conceito é ampliado e adquire concretude quando os fundamentos de sua operacionalização são discutidos por Nuria Cunill Grau (2005), que aponta duas premissas para as ações intersetoriais: a) que a integração possibilita a busca de soluções integrais e assegura um fundamento político à intersetorialidade; e b) a diferença entre os distintos setores que as diferenças entre eles sejam usadas de forma produtiva para a resolução dos problemas. A autora destaca ainda os elementos que compõem o conceito: a integração, a inclusão e o compartilhamento.

Grau (2005) faz uma longa discussão sobre questões latentes no trato da coordenação e da intersetorialidade e apresenta tipos de casos, oferece exemplos de aplicações, faz comparações sobre distintos níveis de integração e enumera alguns casos na América Latina. Entre esses exemplos a autora destaca a experiência das Câmaras Temáticas do governo brasileiro. Surgidas no governo do presidente Fernando Henrique Cardoso têm continuidade no governo do presidente Luiz Inácio Lula da Silva. 
Destaque-se que no Brasil essa questão tem um conjunto de dimensões, as quais permitem perceber que seu enfrentamento não é algo trivial, a começar pela questão federativa, que na essência é conflitiva. Nesse sentido, Abrucio (2005, p. 44) destaca Pierson ao comentar: "Mais do que um simples cabo de guerra, as relações intergovernamentais requerem uma complexa mistura de competição, cooperação e acomodação". E complementa, ressaltando que:

O modus operandi cooperativo é fundamental para otimizar a utilização de recursos comuns, [...]; para auxiliar governos menos capacitados ou mais pobres a realizarem determinadas tarefas; para integrar melhor o conjunto de políticas públicas compartilhadas, evitando o jogo de empurra entre os entes. Ainda é peça-chave no ataque a comportamentos financeiros predatórios, que repassam custos de um ente à nação, como também na distribuição de informação sobre as fórmulas administrativas bem-sucedidas, incentivando o associativismo intergovernamental (ABRUCIO, 2005, p. 44).

Ressalte-se ainda que, para caracterizar o processo de implementação das ações intersetoriais, considera-se fundamental conjugar as perspectivas dos gestores e dos executores diretos das ações desenvolvidas com a experiência de acesso e uso dos beneficiários dessas intervenções.

No caso brasileiro o tema vem adquirindo cada vez maior visibilidade, tanto no meio acadêmico quanto nas organizações do governo, que percebem a dificuldade de enfrentar certos problemas de forma isolada.

Trata-se de uma nova forma de combater as desigualdades sociais e regionais ainda persistentes no Brasil, que continuam se expressando em diversas dimensões e, portanto, necessitam de um enfrentamento mais integrado. Assim, a constituição de instâncias articuladoras de políticas públicas que coordenem as competências de diversos setores do governo torna-se cada vez mais necessária, fazendo as agências governamentais exercitarem sua capacidade de atuação transversal.

No âmbito do desenvolvimento regional, o caminho encontrado para tal forma de atuação foi a institucionalização da Câmara de Políticas de Integração Nacional e Desenvolvimento Regional, criada pelo Decreto n. 4.793, de 23 de julho de 2003, que teve início com dezessete ministérios e depois foi ampliada para 24 instituições ${ }^{1}$.

A finalidade da Câmara, de acordo com o decreto, seria formular políticas públicas e diretrizes para o desenvolvimento das áreas geográficas extremamente pauperizadas, além de coordenar, de forma articulada, as políticas setoriais com impacto regional, com vistas à redução das desigualdades. Seria, portanto, um esforço no sentido de promover o desenvolvimento das regiões partindo da articulação de diversas ações governamentais.

Os documentos de orientação para criação da Câmara apontam alguns aspectos relevantes dessa ação integrada: a) constituição de ambiente favorável à revalorização do planejamento territorial e à integração das políticas públicas, mediante a adequada consideração da dimensão territorial no ciclo da gestão pública; b) abordagem em múltiplas escalas de intervenção; e c) adoção do planejamento estratégico para o ordenamento territorial e para o desenvolvimento regional.

Além disso, os documentos também apontavam para um momento favorável à consolidação de um novo pacto federativo, bem como à ampliação da presença do Estado e da efetividade das suas ações. Há ênfase no desenvolvimento de instrumentos intergovernamentais e de arranjos institucionais que viessem a contribuir para o aperfeiçoamento da cooperação e da coordenação, além da articulação e da integração concertada dos entes federativos e, partindo disso, haveria a focalização das respectivas ações e a promoção da gestão descentralizada e compartilhada das políticas públicas.

Outro aspecto destacado seria a definição de critérios de atuação no território, por meio da identificação de áreas prioritárias para a intervenção das políticas públicas segundo a ótica das desigualdades regionais de renda e das oportunidades de desenvolvimento entre as unidades territoriais do país; a articulação e a alocação dos recursos a serem mobilizados pelas políticas públicas; e a identificação e a priorização de investimentos estratégicos.

Tais parecem ser os aspectos mais relevantes para o que se deseja discutir aqui, embora existam outros pontos destacados nos documentos de referência. Esse conjunto de pressupostos deveria, em tese, fornecer o apoio institucional para o

\footnotetext{
${ }^{1}$ A Câmara originalmente era composta pelos seguintes Ministérios: Casa Civil da Presidência da República; Integração Nacional; Agricultura, Pecuária e Abastecimento; Educação; Fazenda; Saúde; Cidades; Comunicações; Minas e Energia; Desenvolvimento Agrário; Desenvolvimento, Indústria e Comércio Exterior; Meio Ambiente; Planejamento, Orçamento e Gestão; Trabalho e Emprego; Turismo; Transportes; Secretaria Especial de Aquicultura e Pesca e Secretaria-Geral da Presidência da República.
} 
planejamento das ações do governo, na sua dimensão territorial, tendo como ponto central a articulação interministerial, sem que isso viesse a se configurar subordinação entre as agências.

Em face da complexidade encontrada no território e da amplitude de demandas e de políticas públicas, os trabalhos da Câmara foram organizados em Grupos de Trabalho (GT), a saber: a) o GT de Planejamento Territorial, que objetivava a elaboração de um mapa de convergência das ações de governo e a definição da agenda partindo das metas presidenciais; b) o GT das Regiões Metropolitanas (RM), que definiria uma agenda específica para as onze RM prioritárias para o governo em 2004; e c) o GT de Programas Regionais, que propunha a articulação das ações em andamento no âmbito do PPA 2004-2007, mediante a natureza transversal dessas iniciativas, tendo como referência a territorialidade.

A estratégia de ação que orientou o GT de Programas Regionais centrou-se na elaboração de uma Agenda de Compromissos sistematizada da seguinte forma: a) no primeiro momento foram selecionadas áreas prioritárias; b) posteriormente, foram levantadas as iniciativas ministeriais compativeis com o PPA 2004-2007, na forma de programas; c) na etapa subsequente, tais ações foram sistematizadas em quatro blocos - dinamização econômica, infraestrutura econômica, infraestrutura social e organização institucional; e d) por último, foram definidas metas e recursos orçamentários relacionados a cada ação, o que resultou em uma Agenda de Compromissos, publicada, lançada e distribuída para os atores governamentais que integravam o GT.

Esquematicamente, o debate poderia ser expresso em uma função que relacionaria alto grau de adesão, teoricamente formalizada na Agenda de Compromissos, transitando para uma baixa implementação das ações pactuadas para, então, se verificar alta atividade das políticas setoriais dissociadas do documento. Isso expressaria, portanto, o caráter competitivo entre as iniciativas governamentais.

Tal dimensão de análise associa-se estreitamente às vinculações partidárias dos ministros, evidenciando relações que direcionam recursos dos programas federais sob a governança das agências que estavam sob seu comando e privilegiavam unidades da federação em detrimento de outras, notadamente aquelas governadas pelas mesmas legendas.

No entanto, não é possível analisar tais vinculações sem fazer um breve histórico da formação dessa base de sustentação. A eleição de Luiz Inácio Lula da Silva para seu primeiro mandato foi garantida pela coligação de cinco partidos - Partido dos Trabalhadores (PT), Partido Liberal (PL), Partido Comunista do Brasil (PC do B), Partido da Mobilização Nacional (PMN) e Partido Comunista Brasileiro (PCB) -, que aparentavam maior proximidade ideológica, apesar de já se observar alguma heterogeneidade.

Uma vez vitorioso, o governo se deparou com um dilema para garantir a governabilidade do país. Quando contabilizados os partidos da coligação original, o arco parlamentar governista não ultrapassava 130 deputados, o que deixaria o presidente suscetível em relação às demandas e aos projetos encaminhados para apreciação do Congresso Nacional.

Passados dois anos de governo, e em meio a algumas crises, o presidente se viu obrigado a ampliar essa base em nome da garantia de governabilidade do país e incorporou, à aliança, mais treze partidos políticos ${ }^{2}$, revelando uma complexa arquitetura que deveria abrigar todas as legendas, ou ao menos as que contavam com maior número de assentos nas casas legislativas, onde o governo já encontrava dificuldades para garantir a aprovação de projetos de seu interesse.

O mecanismo encontrado para garantir a fidelidade dessa ampla base parlamentar foi a acomodação de partidos por toda a estrutura governamental. A maioria dos ministérios foi entregue às legendas, que indicaram políticos de seus quadros para ocupar as estruturas de direção das pastas. Isso já permitia um primeiro entendimento do complexo cenário político durante o primeiro mandato de Lula, marcado pela negociação de cargos nos órgãos do governo federal e pela disputa entre partidos que desejavam ampliar sua participação na máquina, além de uma inconstância de apoio que levou o governo muitas vezes a "pagar" um alto preço, com a liberação de recursos e favorecimento a determinados grupos e estados em alguns de seus programas, a exemplo do Promeso, discutido a seguir.

\footnotetext{
${ }_{2}^{2}$ Partido do Movimento Democrático Brasileiro (PMDB), Partido Republicano Brasileiro (PRB), Partido Popular Socialista (PPS), Partido Socialista Brasileiro (PSB), Partido Progressista (PP), Partido da República (PR), Partido Trabalhista Brasileiro (PTB), Partido Verde (PV), Partido Democrático Trabalhista (PDT), Partido Social Cristão (PSC), Partido dos Aposentados da Nação (PAN), Partido Trabalhista do Brasil (PT do B) e Partido Humanista da Solidariedade (PHS).
} 


\section{O PROMESO NO CONTEXTO DA COOPERAÇÃO E COMPETIÇÃO INSTITUCIONAL}

A contextualização do cenário político fez-se necessária para a compreensão de alguns aspectos relativos a esta análise, considerando que a Agenda de Compromissos, além de ser um encontro entre ações e agências federais, foi também uma instância de "convívio" entre diferentes legendas partidárias e grupos de interesse bastante heterogêneos.

O Promeso constitui-se uma das principais iniciativas operacionais da PNDR e, segundo os documentos oficiais, tem "como foco a gestão do desenvolvimento alicerçado no estímulo ao potencial e características econômicas, sociais e culturais próprias de cada região". No caso, o recorte geográfico, em escala intermediária entre o macrorregional e o local, passa a se constituir um importante instrumento para as ações governamentais articuladas, aproximando-se mais das populações locais e de suas realidades. Essa importância é destacada nos objetivos enunciados nos documentos de referência do programa:

O Promeso busca: a redução das desigualdades sociais e regionais a partir da potencialização dos ativos endógenos tangíveis e intangíveis de mesorregiões diferenciadas; objetiva induzir a atuação integrada do Governo Federal em novas escalas espaciais, preferencialmente em sub-regiões; promover a identificação de demandas e soluções à chamada problemática regional com a participação efetiva da sociedade civil que, para tanto, deve estar organizada e legitimamente representada e buscar a superação dos desequilíbrios com base no fomento a todas as regiões que apresentem potencialidades e ativos de capital humano e social, parcerias, capacidade de construírem planos e pactos, redes de cooperação entre agentes econômicos, cooperação entre instituições públicas e privadas (Ml, 2010, p. 27).

Nas diretrizes do Programa, estão elencados dois eixos principais: a) organização social; e b) ativação econômica. É importante observar que fica expresso a todo o momento, nos documentos do Promeso, esse caráter intersetorial entre os órgãos de governo e os atores da sociedade civil presentes nas suas regiões-alvo, conforme se verifica no fragmento a seguir, segundo o qual as ações do programa devem se pautar pela: "[...] atuação integrada do Governo Federal em novas escalas especais, preferencialmente em sub-regiões; [...] e buscar a superação dos desequilíbrios com base [...] na cooperação entre instituições públicas" (MI, 2010, p. 27, grifo nosso)

Esse caráter de integração e cooperação esperado se complementa no trecho a seguir, que provoca a "interface entre as diversas ações do governo em espaços específicos" (MI, 2010, p. 12, grifo nosso). Nesse sentido, o entendimento para a instituição de recortes geográficos específicos, para a ação integrada do governo federal, passa pelo entendimento de que a Mesorregião se constitui: "[...] em subespaço político-institucional criado na busca de uma ação territorial mais efetiva e coordenada das políticas públicas com o objetivo de contribuir para a redução das desigualdades regionais, promovendo novas dinâmicas de desenvolvimento" (MI, 2010, p. 27).

O programa encontrava-se sob coordenação do Ministério da Integração Nacional (MI) e executado por seus órgãos vinculados, como a Companhia de Desenvolvimento dos Vales do São Francisco e do Parnaíba (Codesvaf), o Departamento Nacional de Obras contra as Secas (Dnocs), a Superintendência do Desenvolvimento da Amazônia (Sudam) e a Superintendência do Desenvolvimento do Nordeste (Sudene), além de um conjunto de outros órgãos detalhados no Quadro 1. 


\section{Quadro 1}

Interfaces programáticas com o Promeso

\begin{tabular}{|c|c|}
\hline Ministério & Programas \\
\hline Integração Nacional & Conviver/Proágua \\
\hline Agricultura Pecuária e Abastecimento & Apoio ao setor agropecuário \\
\hline Cidades & Saneamento urbano/Infraestrutura urbana \\
\hline Ciência e Tecnologia & $\begin{array}{l}\text { Desenvolvimento educacional e pesquisa tecnológica } \\
\text { Inclusão digital/Inovação e competitividade }\end{array}$ \\
\hline Comunicações & Inclusão digital \\
\hline Desenvolvimento Agrário & $\begin{array}{l}\text { Agricultura familiar/Desenvolvimento Sustentável de Territórios Rurais/ } \\
\text { Reforma agrária }\end{array}$ \\
\hline $\begin{array}{l}\text { Desenvolvimento, Indústria e Comércio } \\
\text { Exterior }\end{array}$ & Arranjos produtivos locais \\
\hline Educação & Desenvolvimento educacional e pesquisa tecnológica \\
\hline Saúde & Saneamento urbano \\
\hline Trabalho e Emprego & $\begin{array}{l}\text { Economia solidária/Emprego, trabalho e renda. } \\
\text { Primeiro Emprego }\end{array}$ \\
\hline Transportes & Infraestrutura de transportes - rodovias \\
\hline Turismo & Turismo no Brasil: uma viagem para todos \\
\hline
\end{tabular}

Fonte: Elaboração dos autores.

O programa tinha seus recursos consignados no Orçamento Geral da União (OGU) e, em algumas situações, esses recursos federais são complementados pelas contrapartidas de estados e municípios.

Para fazer o levantamento sobre a distribuição dos recursos, foi consultado o Sistema Integrado de Administração Financeira do Governo (Siafi) e o Portal da Transparência do Governo Federal mantido pela Controladoria-Geral da União (CGU), separando-os por função programática, nos anos 2005 e 2006. A adoção dos dois exercícios decorreu da preocupação em conferir confiabilidade aos números, considerando que na maior parte das vezes os trâmites burocráticos podem atrasar todo o fluxo, desde a apresentação do projeto até a assinatura do convênio e a liberação dos recursos.

Observa-se pelo Grafico 1 que alguns ministérios cumprem uma proporção considerável das metas acordadas, ao passo que outros deixam de cumpri-las em sua totalidade. Os que apresentam números mais expressivos são exatamente os que têm obrigações junto aos municípios em decorrência dos dispositivos constitucionais. 
Gráfico 1

Dimensões da cooperação e da competição com base no comprometimento

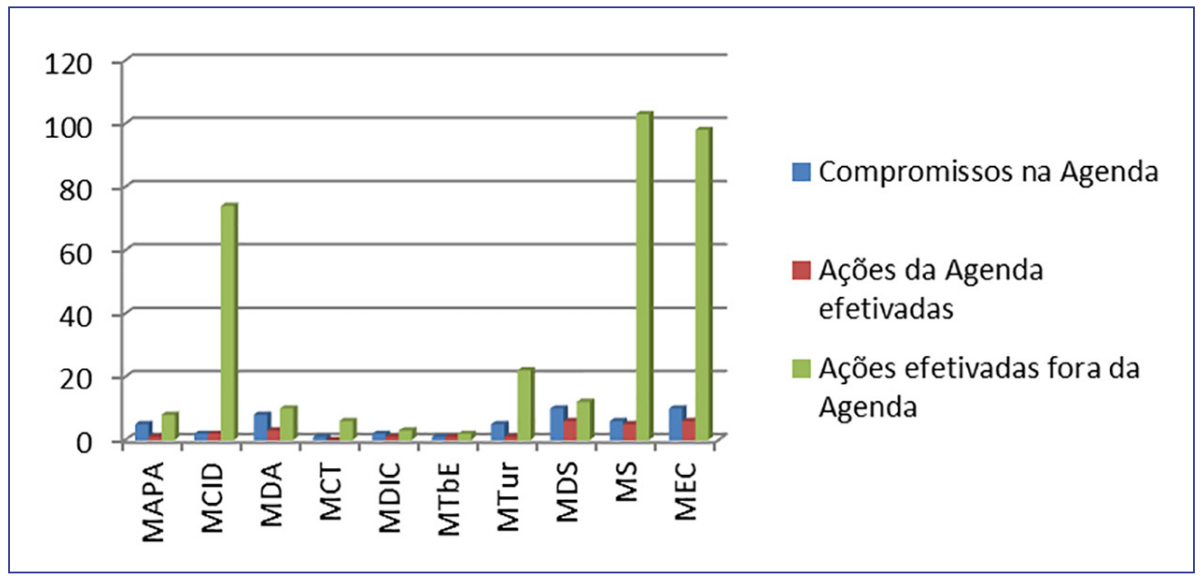

Fonte: Elaboração dos autores.

Esse é um ponto que já evidencia o baixo nível de comprometimento e refere-se às ações pactuadas na Agenda de Compromissos, que, embora elencadas no documento oficial, não são efetivadas do ponto de vista material, pois não se observa nas bases de dados sua formalização por meio de convênios.

No Gráfico, a barra azul seria o compromisso formal, a barra vermelha, o compromisso efetivo e a verde, as ações formalizadas fora da Agenda de Compromissos pelos órgãos partícipes, expressando um caráter competitivo na disputa por recursos, capacidades, visibilidade, prestígio e poder.

No primeiro momento a Agenda de Compromissos, para a Mesorregião do Araripe, mobilizou grande número de agências governamentais em torno das ações propostas; no subsequente, os dados apresentados no Gráfico 2 denotam baixa capacidade de manutenção dessa adesão.

Gráfico 2

Total das iniciativas - evolução 2005-2006

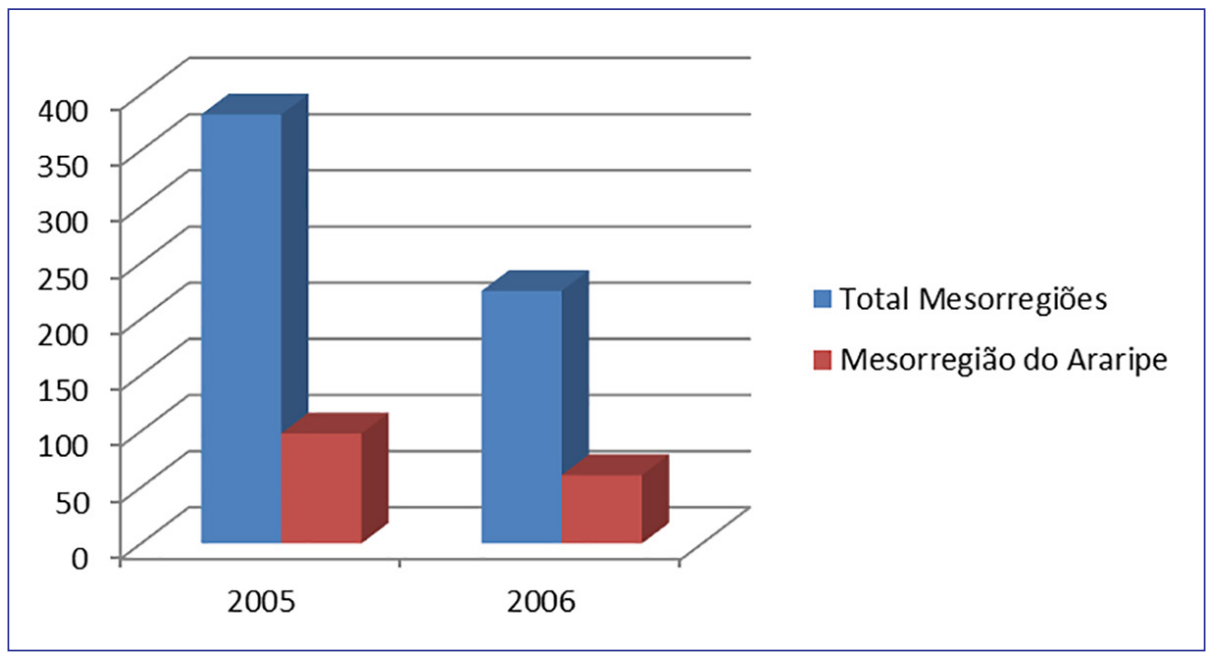

Fonte: Elaboração dos autores. 
No intervalo de um ano as iniciativas foram reduzidas em 1/3; apenas o Ministério da Justiça se incorporou ao esforço da Agenda de Compromissos e cinco ministérios se retiraram, reforçando a baixa capacidade de mobilização e de adesão dos órgãos setoriais.

É fato que, ao "desembarcar" do projeto da Agenda de Compromissos e da Câmara de Políticas de Integração Nacional e Desenvolvimento Regional, tais agências governamentais não deixaram de operar seus programas, embora já não vislumbrassem nessa ação coletiva algo capaz de lhes render algum dividendo político.

Além da fraca adesão observada no período em estudo, constata-se também o pouco comprometimento das demais agências governamentais, uma vez que quase $1 / 3$ das iniciativas assumidas na Agenda de Compromissos não foi concretizada. Os ministérios que apresentam números mais expressivos são exatamente os que têm obrigações junto aos municípios em decorrência dos dispositivos constitucionais.

Portanto, tem faltado à discussão contemporânea estabelecer qual a relação entre o modelo presidencialista de coalizão, o apoio à governabilidade e seus impactos nas políticas públicas do país, em face das lógicas de favorecimento partidária, criando uma verdadeira geografia do favorecimento ${ }^{3}$, como se verifica no tópico a seguir.

\section{“UMA MÃO LAVA A OUTRA": A GEOGRAFIA DOS FAVORECIMENTOS}

Os favorecimentos objeto da discussão ficam evidentes quando os valores transferidos por conveniamento para cada um dos programas/ações que se entrecruzavam com o Promeso na Mesorregião do Araripe 4 são analisados, já evidenciando o baixo comprometimento institucional com a Agenda de Compromissos. Em outra escala os dados ultrapassam o âmbito nacional na busca por demonstrar uma complexa rede que aponta para lógicas na distribuição dos recursos segundo a arquitetura partidária dos governos subnacionais, iniciando-se com o Ministério do Turismo (MTur), conforme mostra o mapa da Figura 1.

\footnotetext{
${ }^{3} \mathrm{O}$ termo aqui tem sentido figurado e visa a esclarecer que, em um país complexo e heterogêneo, há preferências políticas distintas por toda a extensão de seu território, que vinculam as forças políticas locais às estaduais e federais em uma relação de apadrinhamento vertical.

${ }^{4}$ Ressalte-se que, apesar de haver outras Mesorregiões Diferenciadas, a opção pelo estudo de caso se deveu à amplitude da Agenda proposta para a Mesorregião do Araripe, tanto no aspecto horizontal, com 17 órgãos federais, quanto verticalmente, uma vez que inclui 103 prefeituras e 3 governos estaduais. Não há, aqui, a pretensão de fazer uma caracterização profunda da área, pois sua utilização se dá exclusivamente como ponto de partida para a análise empírica.
} 
Figura 1

Mapa de localização dos recursos do MTur, segundo as UF

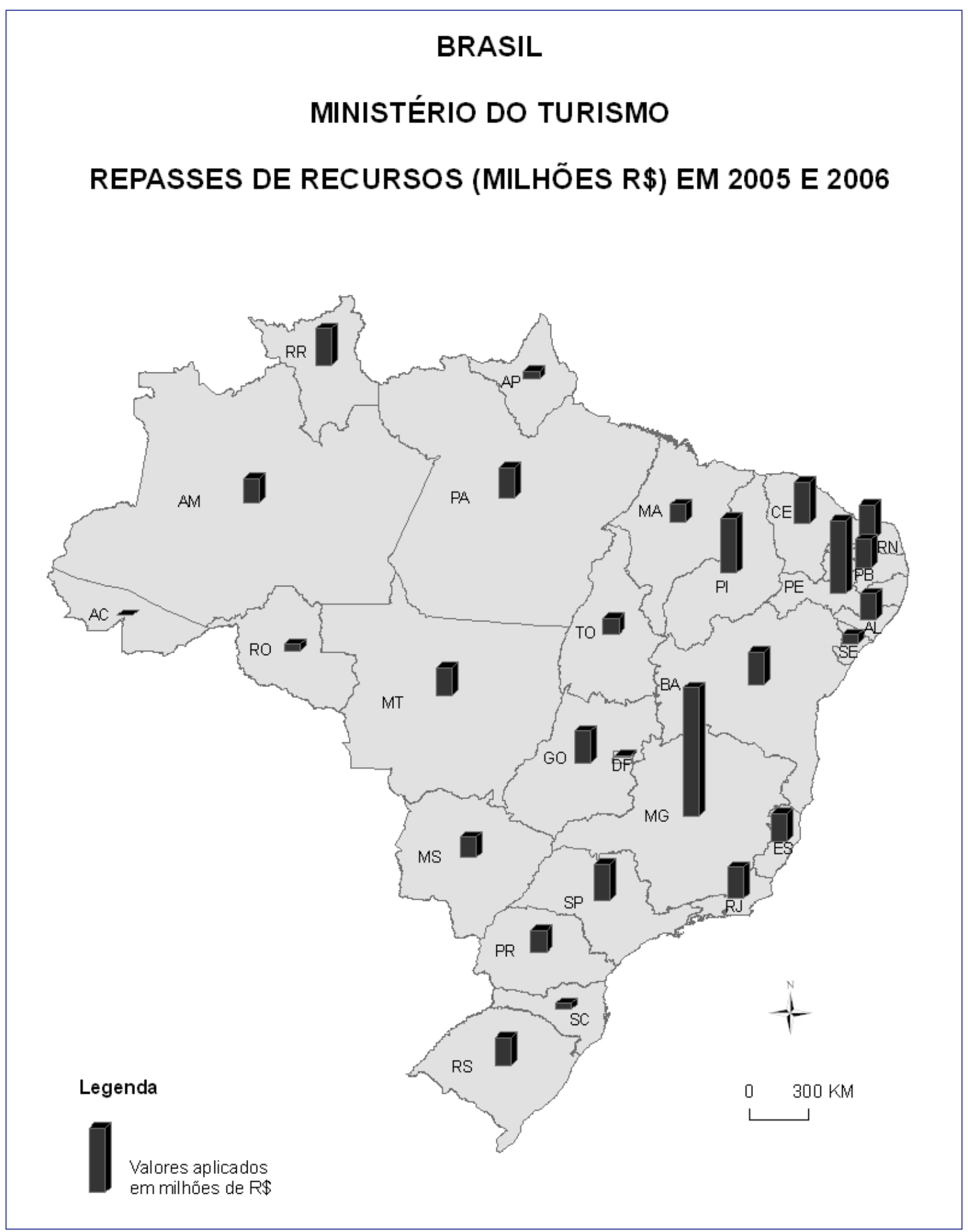

Fonte: Elaborado pelos autores. Portal da Transparência - CGU - extraído em 10/11/2011. 
A titularidade do MTur no período da pesquisa era de Walfrido dos Mares Guia (à época do PTB), que tinha sua origem política em Minas Gerais. No mapa, "salta aos olhos" o montante de recursos destinados àquele estado, que recebeu quase 1/5 de todos os recursos do Programa Turismo no Brasil. O somatório dos valores percebidos por Minas Gerais é superior ao de dez outras unidades da federação juntas.

Apesar de Minas Gerais ser o recordista de valores, o governo estadual, que era da oposição, recebeu pouco mais de $\mathrm{R} \$$ milhões dos R\$ 63 milhões destinados àquela unidade da federação. No entanto, chama a atenção que só a Prefeitura de Belo Horizonte, governada pelo petista Fernando Pimentel, tenha recebido mais de $60 \%$ dos recursos totais para o estado, conforme verificado no Portal da Transparência.

Quando se analisam os números considerando o estado do ministro e demais governos dos partidos da coalizão, o percentual de recursos consignados situou-se no patamar de $65 \%$, ficando para as demais unidades da federação, algumas das quais inclusive de forte pontencial para a atividade turística, apenas 35\% do total de repasses.

Paradoxalmente, na distribuição dos recursos observou-se a participação expressiva do estado do Piauí, que recebeu pouco mais de $6 \%$ do total, embora não seja uma unidade da federação com grande tradição na atividade turística. Isso ocorreu não por acaso, pois no período da pesquisa estava sob o governo do PT.

Outra unidade da federação que chamou a atenção pelo expressivo percentual de recursos consignados foi Roraima, estado igualmente sem tradição na atividade, mas que, além de ter governador da base, também tinha um político - o senador Romero Jucá (PMDB/RR) - que se destacava no Congresso Nacional por, naquele momento, liderar a bancada que apoiava o presidente Lula.

É interessante observar que estados como Santa Catarina, de longa tradição no cenário turístico nacional, tiveram dotações inexpressivas e, coincidentemente, eram unidades da federação governadas pela oposição. A mesma situação se observa em relação ao Ceará e a Goiás, estados de oposição ao governo estadual que tiveram todos os recursos conveniados diretamente com prefeituras ou organizações do terceiro setor, retirando, claramente, os governadores do jogo.

Já os governadores das unidades da federação da base governista em geral receberam recursos. Os melhores exemplos observados são os estados de Pernambuco, Mato Grosso do Sul, Espírito Santo, Amapá, além do Piauí, que receberam repasses diretos do MTur.

Percebe-se, assim, uma lógica que favorece os estados participantes da coalizão, mas também um caminho na distribuição partidária dos recursos. Os números extraídos do Portal da Transparência apontaram que $100 \%$ das unidades da federação sob o comando do PSDB não receberam repasses para o governo estadual. Nesses casos a forma de operar foi via transferências diretas para as prefeituras ou organizações não governamentais (ONG), um mecanismo que diminui a capacidade de barganha dos governadores desses estados e também fortalece a capilaridade dos partidos da base de apoio, sobretudo pelas emendas parlamentares.

Isso não significa que as ações do ministério não estivessem ocorrendo na Mesorregião, pois a Tabela 1 compara o número de ações pactuadas na Agenda de Compromissos e aquelas que, embora fora do documento oficial, foram executadas efetivamente pelo MTur, mediante convênios, ou seja, um conjunto de iniciativas concorrentes. 
Tabela 1

Comparativo entre ações na agenda e ações independentes na região

\begin{tabular}{|c|c|c|c|}
\hline Ministério & Previstas na Agenda & Realizadas & Independentes \\
\hline Turismo & 5 & 1 & 10 \\
\hline Desenvolvimento Agrário & 8 & 3 & 74 \\
\hline Cidades & 2 & 0 & 12 \\
\hline Desenvolvimento Social & 0 & 6 & 98 \\
\hline Educação & 10 & 5 & 102 \\
\hline
\end{tabular}

Fonte: Elaboração dos autores.

Portanto, havia uma agenda de interesses específicos do MTur que o associava às suas vinculações partidárias, bem como aos grupos de interesse que gravitavam em torno de seus programas, não só nacionalmente como também no âmbito sub-regional. Ou seja, o que fora pactuado não precisava necessariamente ser cumprido, para não se colocar a "cereja no bolo" do outro, mas nem por isso a agência setorial deixava de operar para adquirir visibilidade a partir de sua rede de favorecimentos que, em consequência, Ihe traria resultados, sobretudo políticos.

Em se falando das contribuições para a Agenda de Compromissos na Mesorregião do Araripe, o MTur foi um dos que menos cumpriram o acordado no âmbito do GT, executando apenas $1 / 5$ de suas iniciativas.

A seguir apresentam-se as informações relativas ao Programas Desenvolvimento Sustentável de Territórios Rurais e ao Programa da Reforma Agrária, vinculados ao MDA, ocupado no início do governo por dois gaúchos do PT. 
Figura 2

Mapa de localização dos recursos do MDA, segundo as UF

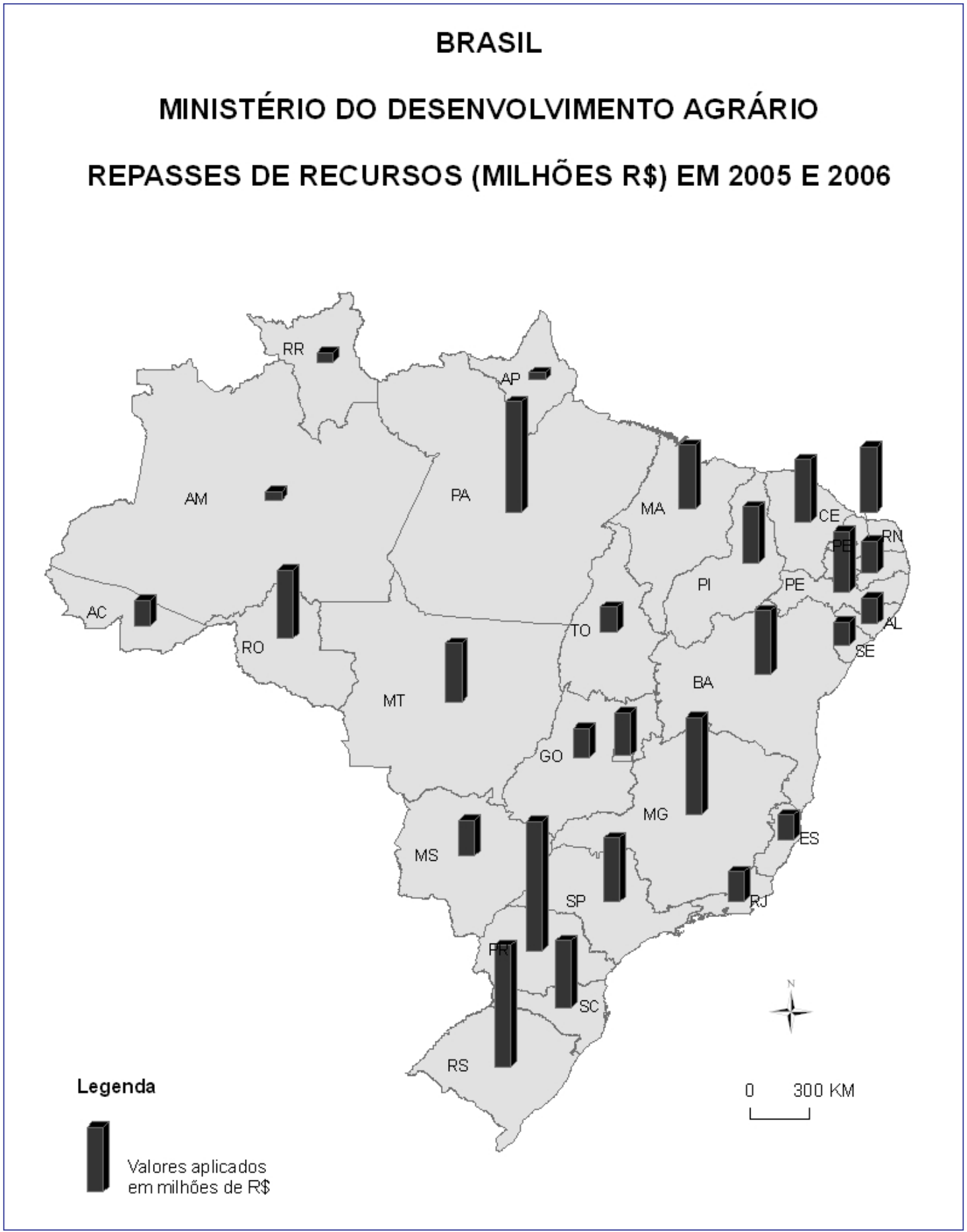

Fonte: Elaborado pelos autores. Portal da Transparência - CGU - extraído em 10/11/2011. 
O mapa da Figura 2 apresenta esquematicamente o total de recursos dos três programas vinculados ao MDA e sua distribuição entre as unidades da federação.

Assim como já foi observado no caso do Turismo, no MDA, o estado dos ministros - Rio Grande do Sul -, ocupa a segunda colocação nos valores consignados de seus programas. Ressalte-se que esses valores eram o somatório de funções programáticas bastante importantes, como o Pronaf, Territórios Rurais e Reforma Agrária. Em alguns desses programas, o Rio Grande do Sul se colocava em primeiro lugar durante todo o período estudado e, mesmo havendo mudanças no ministério, o domínio político não saiu do PT gaúcho. Portanto, a lógica de favorecimento foi mantida.

Das dez primeiras unidades da federação elencadas no quadro do MDA três estavam na Região Sul do país, ou seja, todas daquela região, o que denota claramente um forte viés regionalista.

Essa é uma discussão interessante, pois corriqueiramente a imprensa e alguns setores da sociedade acusam determinadas agências do governo federal de favorecerem o Nordeste ou a Amazônia, fato associado ao MI e ao Ministério do Meio Ambiente (MMA), respectivamente.

No caso, aqui se verifica, também, que esse tratamento distinto pode ocorrer em relação às áreas mais dinâmicas do país, ou seja, se há um "Ministério do Nordeste" ou um "Ministério da Amazônia", também existem "Ministérios do Sul”, "Ministérios do Sudeste". Enfim, parece que essas lógicas regionais sempre permearão as políticas em razão de quem ocupa o ministério e de seus laços com determinados segmentos da sociedade e de grupos de interesse.

Quando se fala em divisão entre situação e oposição, o MDA apresenta equilíbrio, ficando metade dos recursos com cada um dos blocos. No entanto, deve-se ressaltar que parte dos programas da referida agência prescinde da participação dos governos estaduais, operando com base na transferência de recursos para municípios e entidades da sociedade civil organizada. Trata-se de um ministério que se caracterizou pelo forte aparelhamento partidário e pela presença dos grandes movimentos sociais campesinos que apoiaram Lula na sua trajetória política, a exemplo do Movimento dos Trabalhadores Rurais Sem Terra (MST). Alguns estados de oposição - como o Pará -, apesar de apresentarem percentuais expressivos, justificavam esse volume de recursos em face dos problemas agrários que ali se localizavam, e contavam com a forte mobilização desses movimentos sociais que apoiavam o governo.

A lógica observada no MTur se repetiu no MDA, que privilegiou as bases eleitorais dos seus titulares, favorecendo determinados grupos de interesse que negociam seu apoio às políticas do ministério e aos ocupantes de seus cargos de direção, e expressou o viés regionalista na distribuição dos recursos.

Em relação à Agenda de Compromissos, o MDA atingiu pouco mais de 1/3 do que fora registrado no documento, o que, em parte, se explica pelo fato de ter um programa que, parcialmente, concorre com o Promeso, o Territórios da Cidadania. Isso explica a atuação forte do MDA na Mesorregião, conforme se verifica no Quadro 1, com base em uma agenda descolada do GT.

Portanto, o mesmo comportamento observado em relação às escalas nacionais e regionais, no MTur, vai se reproduzindo no MDA, que pactuava menos do que fez, cumpria menos ainda do que fora acordado, e, em contrapartida, mostrava uma expressiva atuação no território descolado desse compromisso integrado com outras agências do governo federal, evitando partilhar seus dividendos políticos.

Outra agência de forte atuação territorial é o Ministério das Cidades (MCid). Os dados aqui apresentados referem-se ao Programa Desenvolvimento Urbano, que atua em todos os municípios brasileiros e distribuiu seus recursos conforme demonstra o mapa da Figura 3. 
Figura 3

Mapa de localização dos recursos do MCid, segundo as UF

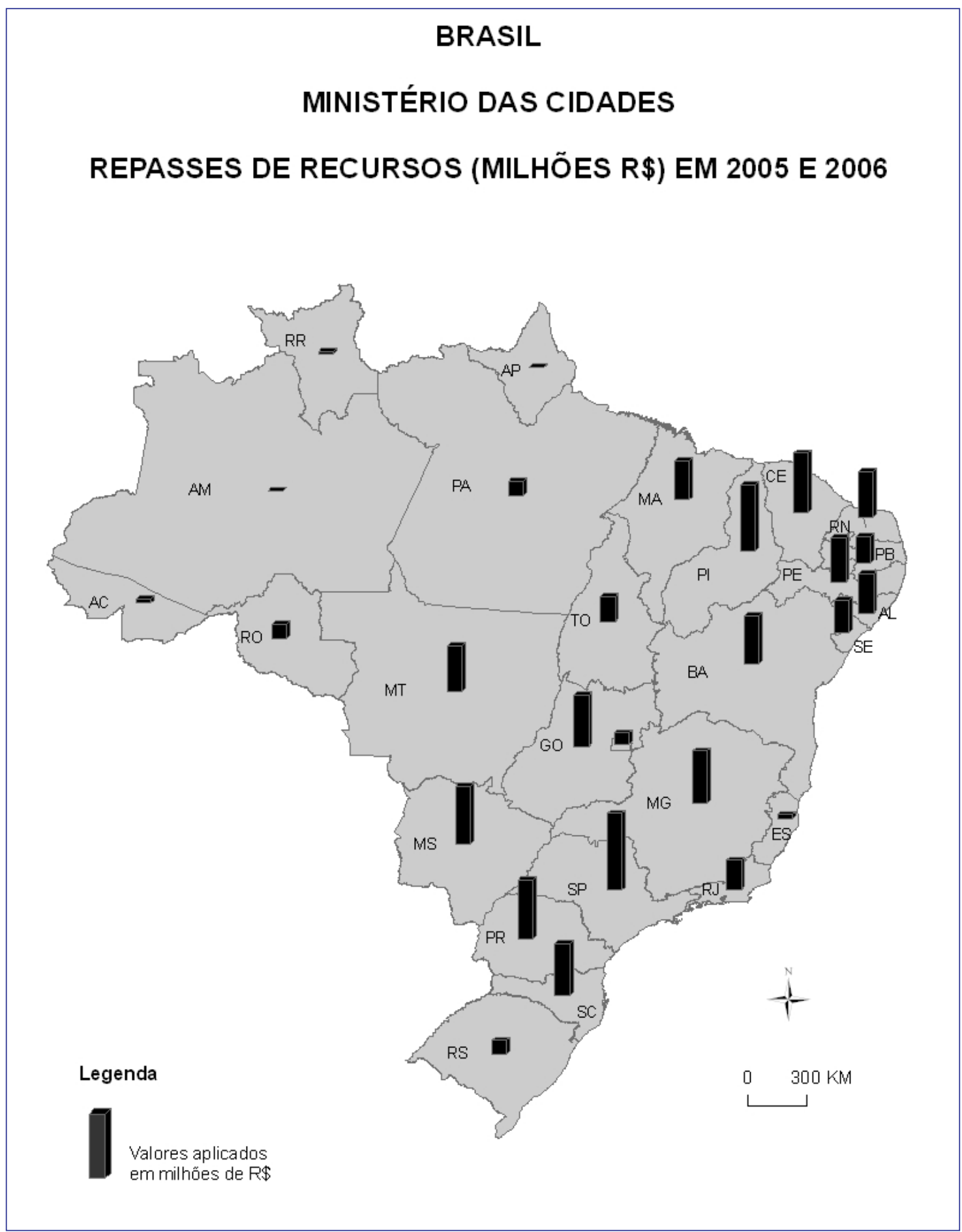

Fonte: Elaborado pelos autores. Portal da Transparência - CGU - extraído em 10/11/2011. 
Apesar de se observar um aparente equilíbrio na distribuição dos recursos, segundo o mapa anterior, os números do Portal da Transparência indicaram alguns traços de favorecimento por parte do MCid na distribuição de suas verbas. Em primeiro lugar, deve-se ressaltar que o Programa se desdobra em duas linhas de atendimento - uma direcionada aos municípios de pequeno porte e outra às cidades médias e grandes. Apesar de interessar a este estudo apenas a primeira, observam-se evidências de favorecimento em ambas.

O orçamento do MCid é bastante pulverizado, operado exclusivamente por transferências via convênios com os estados e os municípios, o que permitirá seu uso para barganhas e ganhos políticos. Quando se observam os dados referentes aos pequenos municípios, identifica-se essa dispersão, o que em um primeiro momento poderia soar como um tratamento mais equânime e republicano por parte do MCid. Essa é uma verdade parcial considerando-se que, distribuídos entre muitos, os valores são baixos, não permitindo a execução de obras de maior envergadura que viessem, de fato, a modificar ou a melhorar a infraestrutura das cidades contempladas. Em geral, são recursos destinados à pavimentação, ao arruamento, a praças e a obras do gênero, o que no jargão da política nacional se chama de "perfumaria".

Tal situação se agrava pelo fato de haver grande número de emendas parlamentares demandando esse tipo de obra e, como os deputados "atendem" a um número considerável de prefeituras, é natural que seus pleitos sejam bastante pulverizados e desconexos, sem vincular-se a planos e a ações de forma articulada.

As obras de maior envergadura, em geral, ficam para os municípios de médio e grande porte, que muitas vezes as recebem em razão da força das bancadas ou de quem está à frente da Prefeitura. Isso ficou evidente na consulta aos dados quando foram observados exemplos desse favorecimento, de norte a sul do país, tal como ocorreu com o município de Londrina, que recebeu todo o montante destinado para os médios e grandes municípios do Paraná e estava sob o governo do PT; ao passo que Curitiba, capital do estado onde o PT tinha sido derrotado, e estava sob a gestão do PSDB, não teve repasses. Outro bom exemplo é Nova Iguaçu, no estado do Rio de Janeiro, que sozinha recebeu $75 \%$ dos valores da linha de grandes e médias cidades, ao passo que a cidade do Rio de Janeiro, governada pelo PFL (atual DEM), não obteve recursos ou, ainda, o município de Dourados, no Mato Grosso do Sul, governado pelo PT, que recebeu 2,5 vezes o valor da capital, Campo Grande, governada pelo PSDB.

Para que não fique nenhuma região de fora, vale o exemplo de Ananindeua e Santarém, no Pará, governadas pelo PT e seus coligados, que juntas receberam 25 vezes mais recursos que a capital, Belém, onde o PT tinha sofrido outra grande derrota. Por fim, o estado do Piauí, onde a capital Teresina não teve repasses e o governo estadual, do PT, recebeu todo o valor enviado àquela unidade da federação.

Quanto à participação do MCid na Agenda de Compromissos, poderia-se dizer que foi de $100 \%$, uma vez que as duas ações que o ministério propôs, de fato, foram executadas transformando-se em repasses. No entanto, é exatamente o MCid que apresenta a maior agenda concorrente. Nessa agenda, notou-se forte tendência de apoio ao único governador do PT na Região Nordeste, Wellington Dias, e ficou expresso o favorecimento ao estado do Piauí, que está entre as três unidades da federação que tinham municípios na Mesorregião do Araripe.

Ao se examinar os dados, verifica-se que $56 \%$ dos municípios da Mesorregião localizados no Piauí foram objeto de ações do MCid, contra $28 \%$ dos municípios pernambucanos e $32 \%$ dos cearenses, o primeiro estado governado pelo PMDB, mas com um titular, Jarbas Vasconcelos, que por várias vezes fez oposição ao presidente da República, e o segundo, pelo PSDB, com o governador Lúcio Alcântara.

Como dito anteriormente, o MCid opera a partir de pequenas obras, sobretudo nesses municípios menores, característicos da Mesorregião do Araripe. Nesses, portanto, esse conjunto de ações presta um enorme serviço para os grupos políticos interessados em manter o conjunto de municipalidades sob seu domínio.

O mapa da Figura 4 mostra como se distribuem, entre as unidades da federação, os recursos do Ministério do Trabalho e Emprego (MTE), seguindo a mesma lógica já discutida em relação aos ministérios citados. 
Figura 4

Mapa de localização dos recursos do MTE, segundo as UF

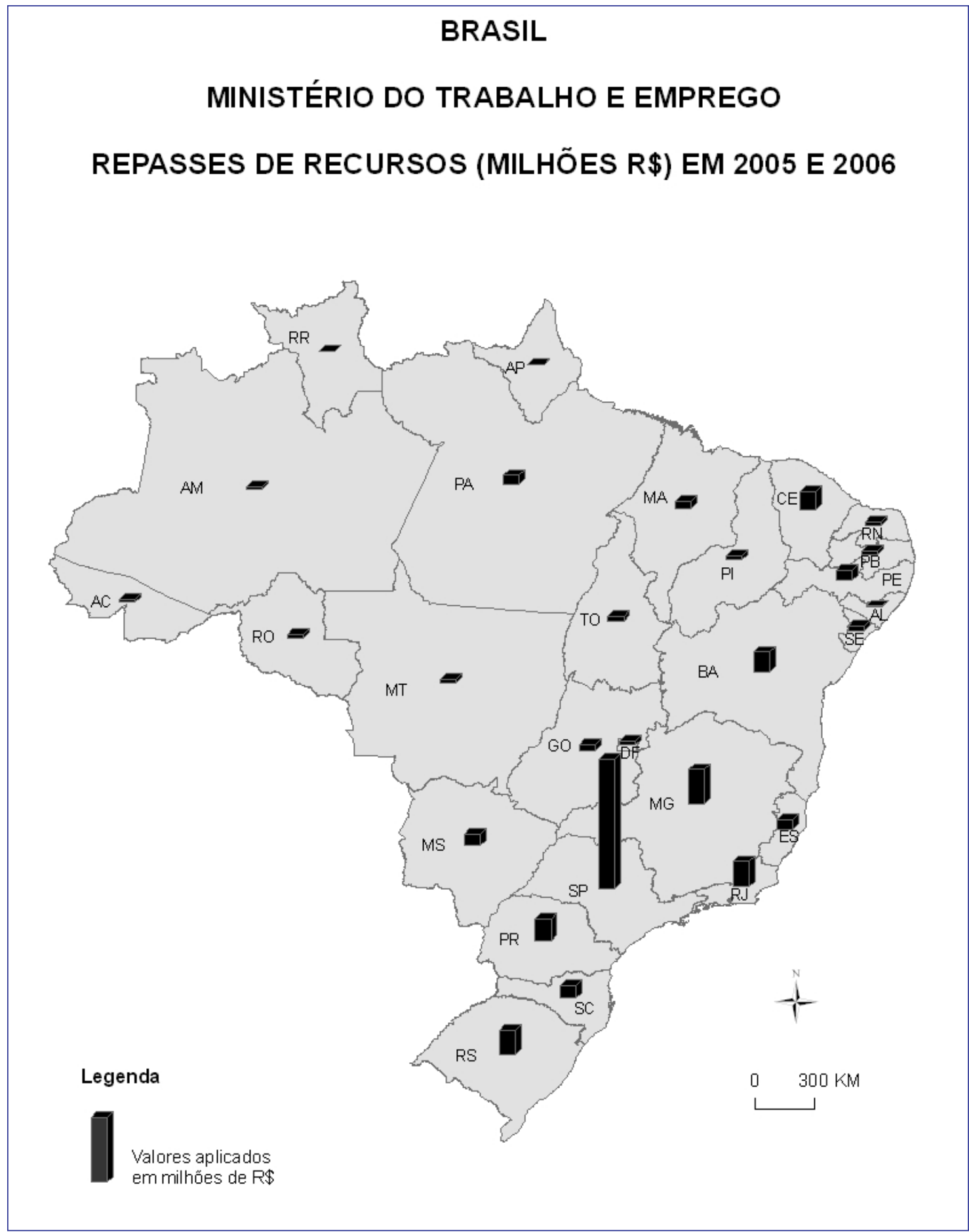

Fonte: Elaborado pelos autores. Portal da Transparência - CGU - extraído em 10/11/2011. 
Apesar de São Paulo ser um estado da oposição, confirma-se a existência de uma lógica similar aos casos citados, em que o estado dos ministros (Ricardo Berzoini e Luis Marinho) é de longe o mais bem aquinhoado pelos recursos dos programas do MTE, recebendo mais de $1 / 3$ do total. Isso se explica não só pela origem geográfica, mas, também, pelo forte apoio recebido do movimento sindicalista, que tem em São Paulo suas mais expressivas lideranças e as maiores centrais de trabalhadores. Esses segmentos historicamente apoiaram o PT e é claro que sempre estiveram ligados às políticas públicas correlatas à regulação das relações empregatícias e de qualificação dos trabalhadores, o que naturalmente as levaria para o interior das estruturas da agência federal responsável pelo tema, aparelhando-a fortemente. O melhor exemplo dessas relações tão estreitas se evidencia não só pelo expressivo valor destinado a São Paulo, mas, sobretudo, pelos números consignados à Força Sindical Nacional e à Central Única dos Trabalhadores (CUT), além do Departamento Intersindical de Estatísticas e Estudos Socioeconômicos (Dieese), que, sozinhos, receberam cerca de $80 \%$ dos recursos destinados à capacitação (Ação 2550 - Orientação Profissional e Intermediação de Mão de Obra) naquele estado, segundo os dados do Portal da Transparência. As três entidades, em conjunto, receberam nos dois anos estudados e em todos os programas/ações do MTE cerca de $20 \%$ do total destinado ao estado de São Paulo.

Deve-se destacar que boa parte dos programas do MTE relativos à capacitação do trabalhador e à economia solidária se faz por transferência voluntária, via convênios para entidades não governamentais, o que facilita sua operação sem intermediação dos governos estaduais, principalmente dos de oposição.

Os números expressam também a lógica do apoio regional, sobretudo para estados onde o PT não tinha tradição, como Mato Grosso do Sul, governado, à época, por Zeca do PT, que recebeu valores superiores a todos os demais estados da Região Centro-Oeste, alguns dos quais, inclusive, com maior população e mais expressão econômica.

A atuação do MTE na Mesorregião do Araripe é incipiente no que se refere à sua participação no GT e na Agenda de Compromissos, onde apenas uma ação foi consignada e efetivamente cumprida, número igual ao de iniciativas que ocorreram independentemente.

O artigo prossegue na análise dos dados referentes aos programas/ações do Ministério da Ciência, Tecnologia e Inovação (MCTI) e sua distribuição entre as unidades da federação, conforme mostrado no mapa da Figura 5. 
Figura 5

Mapa de localização dos recursos do MCTI, segundo as UF

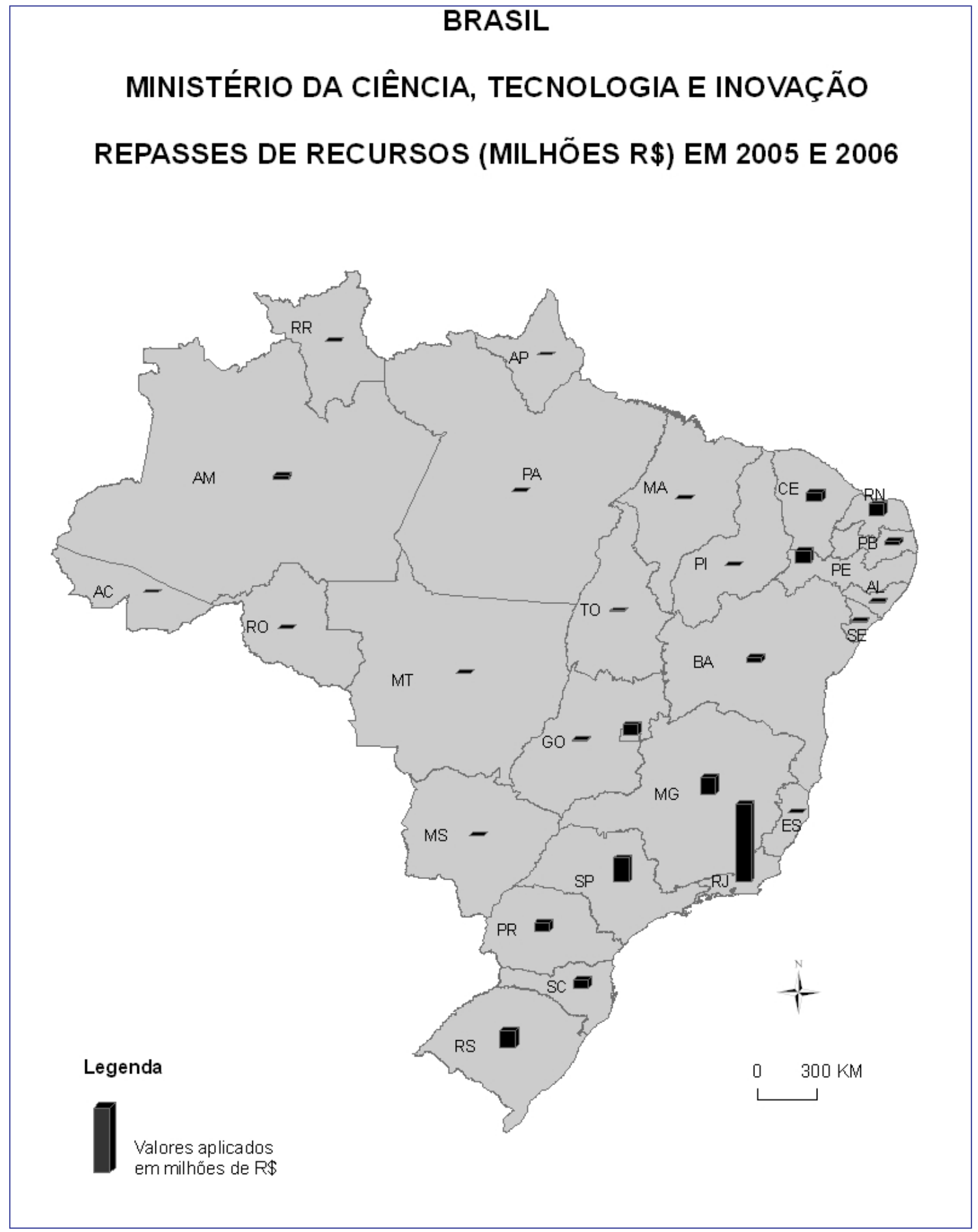

Fonte: Elaborado pelos autores. Portal da Transparência - CGU - extraído em 10/11/2011. 
O mapa revela quão expressiva foi a participação do estado do Rio de Janeiro na distribuição do orçamento do MCTI. Não por acaso, trata-se do local de origem do ministro Roberto Amaral, que ocupou a pasta no início do primeiro mandato do presidente Lula, até meados de 2005, e foi sucedido por Eduardo Campos, já falecido, e que ocupou o cargo de governador do estado de Pernambuco, ambos filiados ao PSB.

Observa-se uma tendência na destinação dos recursos para o Rio de Janeiro e, em algumas das iniciativas do MCTI, essa unidade da federação aparece como única beneficiária, a exemplo da Ação 4147 - Fomento à Capacitação Tecnológica em Temas de Impacto Social, em que o estado recebeu sozinho mais de R\$ 6 milhões, ao passo que a segunda unidade da federação a receber mais recursos, o Distrito Federal, obteve $\mathrm{R} \$ 85$ mil. Esse mesmo padrão é observado em relação ao partido dos dirigentes, sobretudo na Região Nordeste, onde, além de Pernambuco, o estado do Rio Grande do Norte recebeu verbas em percentuais superiores às demais unidades da federação, algumas das quais com mais tradição na área de ciência e tecnologia. Ressalte-se que na ocasião o governo potiguar estava sob o comando de Wilma de Farias, também do PSB. O partido tinha quatro governadores no país, sendo três deles no Nordeste; só o Rio Grande do Norte e Pernambuco responderam com mais da metade de toda a verba para a área de ciência e tecnologia destinada à região.

Para a Agenda de Compromissos a participação do MCTI foi praticamente nula, uma vez que o ministério assinalou uma única ação - que seria desenvolvida com o MI e, mesmo assim, não a realizou. Por outro lado, o MCTI colocou de pé um conjunto de seis ações, de forma independente, adotando um posicionamento similar aos demais, formalizando compromissos no papel, sem que necessariamente esse comprometimento se tornasse uma ação concreta. Assim, replica-se no MCTI o mesmo padrão já observado nos demais ministérios, de operar segundo lógicas setoriais, partidárias e de favorecimento a grupos de interesse via uso da máquina, para conferir visibilidade a seus projetos.

A análise prossegue mostrando os resultados apresentados pelo Ministerio do Desenvolvimento Social e Combate à Fome (MDS), localizando esquematicamente no mapa da Figura 6 como se dá a distribuição dos recursos entre as unidades da federação. 
Figura 6

Mapa de localização dos recursos do MDS, segundo as UF

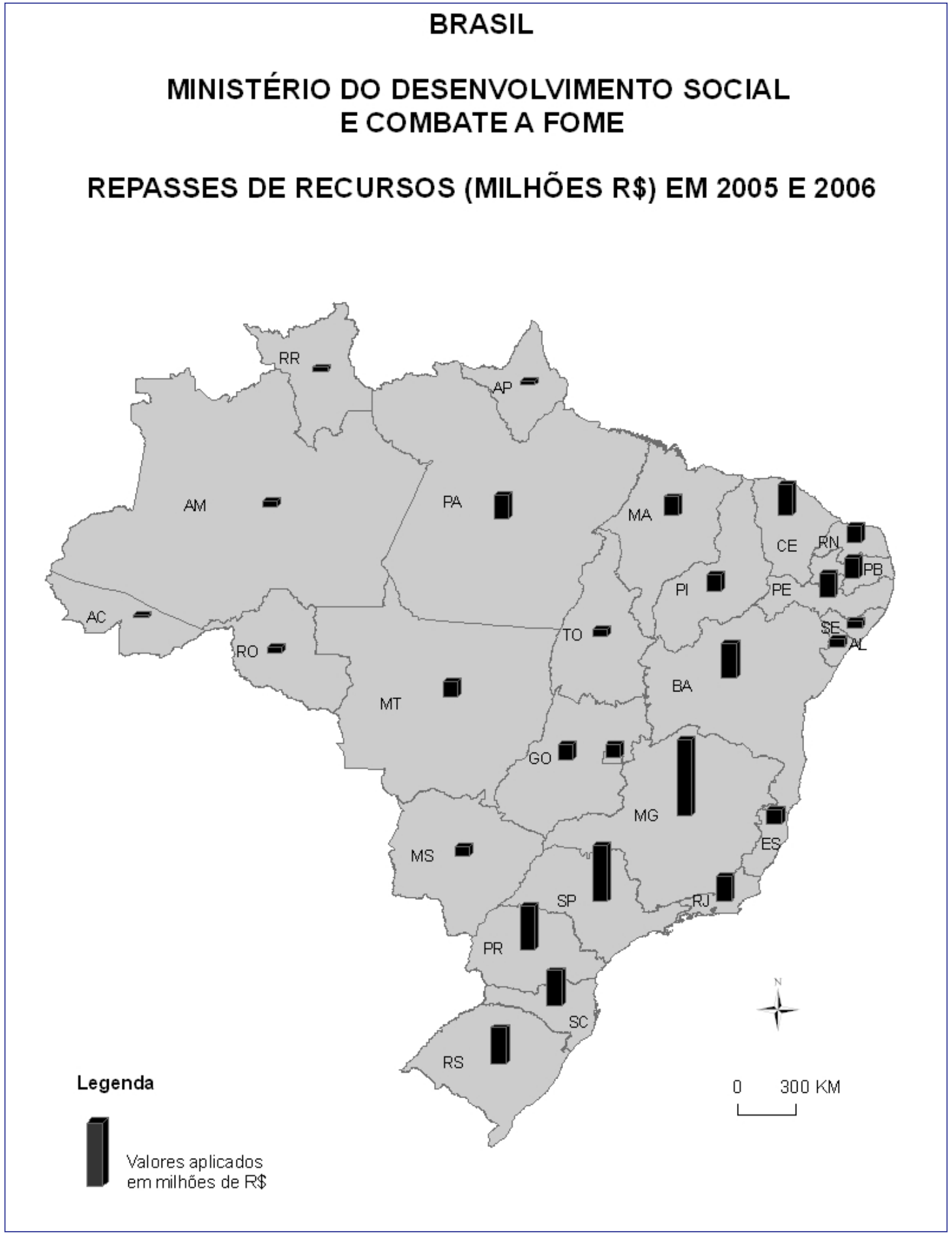

Fonte: Elaborado pelos autores. Portal da Transparência - CGU - extraído em 10/11/2011. 
O mapa da Figura 6 mostra as tendências de localização dos recursos e permite ver em detalhes os números relativos aos programas/ações do MDS, possibilitando as inferências. No caso do MDS deve-se esclarer que foram expurgados os valores do Programa Bolsa Família (PBF) e dos demais Benefícios de Prestação Continuada (BPC), que poderiam afetar os números. Assim, foram analisadas apenas as ações relativas à inclusão social e produtiva, que se interconectam com o Promeso, atendendo às populações em situação de vulnerabilidade.

Deve-se ressaltar que o PBF foi o programa social de maior visibilidade no governo do presidente Lula e foi constantemente mencionado como uma das mais importantes iniciativas na área nos últimos anos, senão a mais importante. Uma ação dessa natureza e expressividade naturalmente não poderia deixar de ficar nas mãos do partido do chefe do Executivo, que, daí em diante, apesar das trocas ministeriais, jamais deixou de ter a titularidade da pasta.

Aqui se observa, novamente, o padrão de favorecimento ao estado do ministro - no caso, de Minas Gerais, que recebeu recursos bem mais expressivos do que todos os demais. E isso não está relacionado à proporcionalidade da população, pois São Paulo, que é o estado mais populoso da federação, fica em segundo lugar, recebendo apenas $70 \%$ do que se destina a Minas Gerais.

Ainda sobre essa concentração de recursos, verifica-se que não há uma lógica técnica nas transferências, uma vez que os estados da Bahia e do Maranhão concentram os maiores contingentes de população em situação vulnerável, em números absolutos e proporcionais, respectivamente.

Outra indicação dessa ausência de caráter técnico é revelada pela consignação de recursos para os estados do Paraná e de Santa Catarina, que receberam valores superiores ao Ceará e à Bahia, estados reconhecidamente marcados pela pauperização de grandes contingentes populacionais. No entanto, dois aspectos chamam a atenção: primeiro, a proporcionalidade desse público-alvo varia muito e, sabe-se, se concentra nas regiões Norte e Nordeste do país. O segundo aspecto evidente, que põe por terra uma possível distribuição isenta de fatores políticos, é o fato de que a maior parte das ações do MDS se dá pela transferência de recursos para prefeituras e organizações não governamentais. Portanto, o uso da máquina para fortalecer a presença do governo central nas municipalidades, já tão evidente em face do PBF e dos BPC, é reforçado pelas demais ações do ministério.

É visível o baixo desempenho do MDS nos compromissos assumidos perante o GT e consignados na Agenda de Compromissos. Como já dito, ao se expurgar as ações de transferência de renda e benefícios, observou-se que nenhuma das outras iniciativas assinaladas concretizou-se mediante a formalização de convênio. Por outro lado, o ministério implementou na área da Mesorregião doze ações sem que essas fossem incorporadas à Agenda de Compromissos, embora já estivessem previstas em seu orçamento, adotando uma atitude avulsa que concorria com a ação integrada.

Conforme já explicitado, o MDS coordena o mais importante programa da área social do governo federal, o PBF, de grande visibilidade e capilaridade, em virtude de seu desenho. No entanto, estão sob seu comando outras importantes ações que poderiam ser tratadas de forma integrada no escopo da política social, sobretudo as relacionadas à inclusão produtiva de populações vulneráveis. Pode ser que aí resida a explicação dessa ação insulada por parte do MDS, uma vez que a "grife" do ministério já está incorporada aos grandes contingentes populacionais que habitam as áreas mais pobres do país, em virtude da forte presença do seu programa de transferência de renda e de outros benefícios sociais. Assim, ações complementares, sob sua governança, reforçariam seu poder junto aos beneficiários dessas iniciativas, bem como perante as municipalidades. Não por acaso, vários estudos, inclusive do Instituto de Pesquisa Econômica Aplicada (Ipea) ${ }^{5}$, mencionam tais políticas como motores das economias locais e, consequentemente, fomentadoras do desenvolvimento regional.

A análise passa agora aos dados do Ministério da Educação (MEC), distribuídos geograficamente e localizados no mapa da Figura 7, observando-se a existência de algumas lógicas particulares. A principal ação do ministério que se entrecruza com o Promeso é a de Implantação e Recuperação dos Centros de Educação Profissionalizantes, que constrói e reforma escolas técnicas.

\footnotetext{
${ }^{5}$ Para mais informações, consultar o Texto para Discussão, n. 1647, intitulado Perfil da pobreza no Brasil e sua evolução no período 2004-2009, de Rafael Guerreiro, Pedro Sousa, Sergei Soares e Luis Felipe de Oliveira.
} 
Figura 7

Mapa de localização dos recursos do MEC, segundo as UF

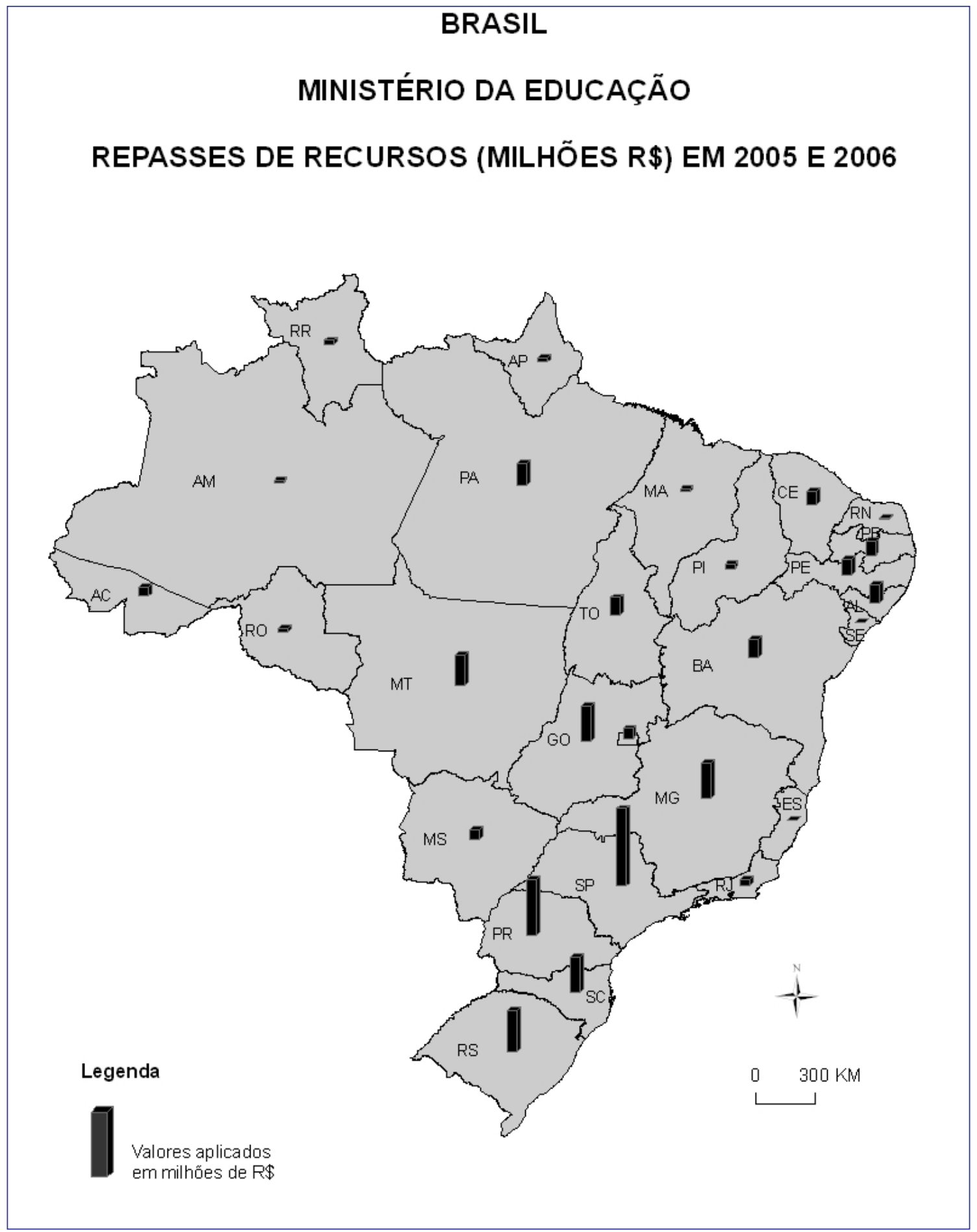

Fonte: Elaborado pelos autores. Portal da Transparência - CGU - extraído em 10/11/2011. 
A primeira revelação do mapa é a expressiva participação de São Paulo, que recebeu $16 \%$ do valor total dos recursos consignados ao Programa de Estruturação do Ensino Profissionalizante, embora seja uma unidade da federação com capacidade de financiar tais ações. Entretanto, também é o estado de origem do titular da pasta - Fernando Haddad. A forma de operar os recursos do programa se dava por conveniamento para entes públicos ou organizações da sociedade civil, o que permitia, sobretudo na área de capacitação, maior capilaridade do governo federal e fortalecia sua presença junto aos municípios e aos grupos apoiadores da candidatura e gestão do presidente Lula. Constatação feita ao se abrirem os dados do Portal da Transparência, que possibilitaram observar a presença de fundações e associações que notadamente têm orientação político-partidária de esquerda, a exemplo do Sindicato de Metalúrgicos do Grande ABC, onde o presidente da República iniciou sua vida política.

Tal comportamento é constatado, também, quando se examinam os valores consignados para as unidades da federação que têm governadores da oposição. Segundo dados do Portal da Transparência, o governo da Bahia recebeu quase R\$ 490 mil, ao passo que uma única ONG recebeu R\$ 2,6 milhões; o governo de São Paulo recebeu R\$ 1,2 milhão e uma única associação classista recebeu o mesmo valor e, no estado de Minas Gerais, o governo recebeu $R \$ 640$ mil, ao passo que uma obra social na cidade de Contagem teve consignado $1 / 3$ do valor total do estado e o equivalente a 1,5 vez o valor destinado ao governo estadual.

Os privilégios a determinadas unidades da federação reforça a má distribuição regional dos recursos, conforme se verifica pelos valores consignados. Só o estado do ministro representava $90 \%$ do valor total alocado para os nove estados da Região Nordeste, o que totalizava pouco mais de $\mathrm{R} \$ 25$ milhões, quase se igualando ao Centro-Oeste, com $\mathrm{R} \$ 24$ milhões, e sendo em muito superada pela Região Sul, que ficou com mais de R\$37 milhões. Esse desequilíbrio é um fator de consolidação das desigualdades regionais, uma vez que a formação de mão de obra qualificada constitui-se um importante fator para tornar os territórios atrativos ao setor produtivo e, portanto, promover o desenvolvimento das regiões.

O fato de ser uma ação que resulta na implantação ou na reforma de unidades de ensino garante maior visibilidade ao programa e, em consequência, ao MEC, possibilitando o uso político da iniciativa, que explicaria o seu bom desempenho quando avaliado o número total de compromissos assumidos e os que efetivamente se concretizaram, conforme demonstrado no Quadro 1. A competição aqui se expressa não exclusivamente por baixa adesão ao que foi assinalado na Agenda de Compromissos, mas, principalmente, pelo espaço que o tema educação ocupa. Cite-se, ademais, que há infinitas possibilidades de implementar ações de maior visibilidade, como construção, reforma ou aparelhamento de escolas de todos os níveis de ensino. Assim, ter uma agenda que se faz hegemônica diante de quaisquer outras iniciativas de coordenação parece ser algo muito comum aos grandes ministérios, como o da Educação. Essa mesma forma de operar, marcada pela capilaridade e pela visibilidade, ocorre com os programas do Ministério da Saúde (MS) que tem interface com o Promeso, conforme verificado no mapa da Figura 8 e que mostra a distribuição dos recursos. 
Figura 8

Mapa de localização dos recursos do MS, segundo as UF

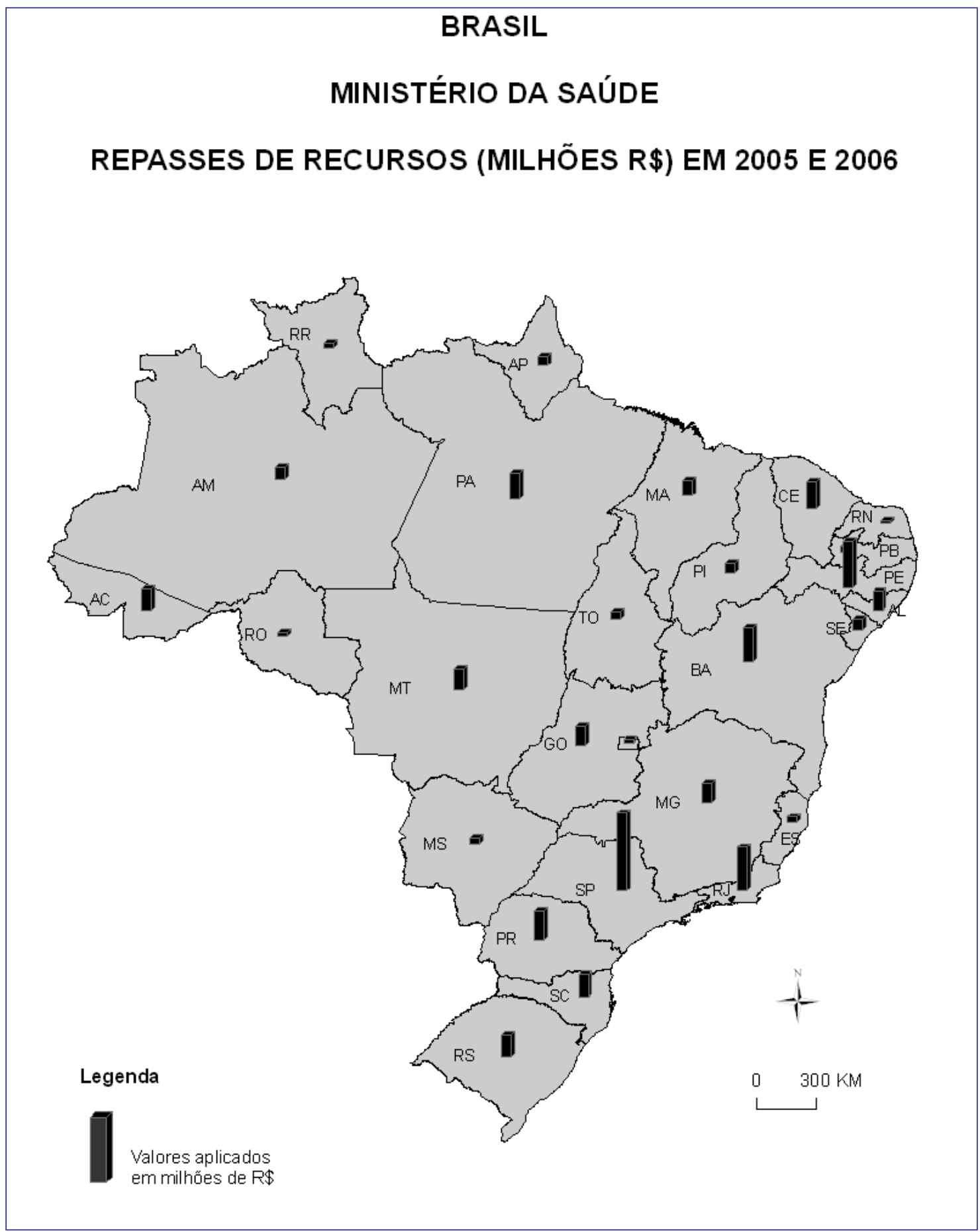

Fonte: Elaborado pelos autores. Portal da Transparência - CGU - extraído em 10/11/2011. 
O mapa comprova os mesmos padrões de operação com viés político-partidário e de favorecimento a determinadas unidades da federação, em decorrência da origem dos dirigentes do MS. Não por acaso, Pernambuco e Bahia estão entre os cinco mais bem aquinhoados com recursos e são os estados de origem dos ministros Humberto Costa (PT) e José Saraiva Felipe (PMDB).

A ação do MS é operacionalizada por transferências voluntárias, exclusivamente para as instâncias governamentais. São flagrantes os favorecimentos partidários ocorridos nos estados da oposição, como São Paulo, onde o governo estadual recebeu $25 \%$ do total dos recursos - valor igual ao de um único município, Guarulhos, que estava sob o comando do PT - e a maior parte dos recursos ficou nas mãos de prefeituras dos partidos da coalizão.

No entanto, esse mesmo padrão de favorecimento é constatado em relação às unidades da federação que têm governos dos demais partidos da base aliada. No estado do Rio de Janeiro, então dirigido por Rosinha Garotinho (PSB), só o município de Nova Iguaçu, governado por Lindbergh Farias, do PT, concentrou $80 \%$ dos recursos totais.

Assim como sucede no setor da educação, o MS aparece com um percentual expressivo de ações constantes na Agenda de Compromissos cumpridas efetivamente, outras ocorrem de forma independente. As razões de tal desempenho são semeIhantes ao que ocorre com o MEC, uma vez que são feitas a partir do Sistema Único de Saúde (SUS) e da Fundação Nacional de Saúde (Funasa), importantes instrumentos nessa relação interfederativa.

Analogamente ao que acontece com as pastas da educação e do desenvolvimento social, o MS tem ficado sob o comando do PT, com alguns momentos de alternância com o PMDB. Mas quem quer que esteja à frente da agência tem nas mãos uma poderosa e capilarizada máquina, considerando-se os vultosos recursos que lhe são destinados, assim como a natureza dos serviços oferecidos, de primeira necessidade para a população.

Há uma lógica que favorece o partido detentor do cargo majoritário e beneficia as legendas que prestam apoio e garantem a governabilidade, o que se expressa na distribuição dos recursos em estreita associação com as bases geográficas dos ministros e dos demais políticos de seu partido.

Adicionalmente, observa-se uma lógica de irrigação de recursos em direção às municipalidades - se pertencentes à base governista, como forma de reforçar sua presença e "pagar" pelo apoio; se oposicionistas, como maneira de fragilizar os que antagonizam o governo e, assim, fortalecer as legendas no poder.

De modo similar, tais ações patrocinaram agrupamentos da sociedade civil que thes ofereceram apoio e garantiram governabilidade, minimizando ou negociando possíveis conflitos. Isso se deu, sobretudo, com as organizações que têm maior mobilização e visibilidade na sociedade civil.

Portanto, verificam-se pontos de convergência, mas também lógicas particularizadas que se estruturam com base na engenharias institucionais, políticas, partidárias e setoriais, para distribuir recursos públicos, oriundos dos programas.

\section{CONSIDERAÇÕES FINAIS}

É importante destacar, ao encerrar o artigo, que o debate encontra seu lastro inicial no funcionamento do modelo presidencialista brasileiro e nas interferências dessa relação no conjunto das políticas públicas, enfatizando as que operam por intermédio da coordenação de várias outras ações que estão sob o mandato de agências do governo federal.

São traços observados, sobretudo, nas agendas partilhadas em que essas agências assumem compromissos, entre si, para trabalharem de forma integrada na condução de determinadas políticas que necessitam de um tratamento mais transversalizado. Na maior parte das vezes, esses pactos se tornam instrumentos esvaziados de conteúdo e efetividade, do ponto de vista da ação coordenada, e dão lugar a uma atuação predatória, na qual as instituições deixam de lado a orientação da intersetorialidade e caminham para a construção de agendas particulares, com vistas ao atendimento de interesses pessoais, políticos e corporativos.

$\mathrm{O}$ artigo evidenciou essa trajetória que, iniciando-se em um aparente acerto na esfera política, no curso do processo vai se desfazendo, para resultar em agendas e acertos pontuais que favorecem os dirigentes das agências e resguardam o espaço delas no cenário de disputas. 
Dizemos que há competição porque essa forma isolada de atuar necessita do aporte de recursos e capacidades e são esses fatores que colocam as agências governamentais na arena concorrencial, onde vencem as mais fortes, ou, melhor dizendo, as que têm mais espaço na agenda ou são conduzidas por partidos e políticos de maior expressão. Para as instituições ocupadas por quadros políticos de menor visibilidade, resta disputar esses recursos em uma luta desigual que, muitas vezes, inviabiliza sua sobrevivência como operadoras de políticas públicas.

Tal fato pode indicar uma tendência à "partidarização" das políticas públicas, adotadas para assegurar projetos de poder, das legendas e de indivíduos. As agências federais, seus recursos e programas são usados como instrumentos de barganhas e trocas com a finalidade de angariar apoio no jogo político. Essa forma de operar tende a impor lógicas particularizadas por parte das agências federais, que se regulam mais por questões políticas e menos pelo aspecto técnico nas ações governamentais. Trata-se de uma característica nefasta daqueles que ocupam as estruturas do Estado brasileiro, pois vai incidir diretamente na qualidade dos gastos governamentais e na eficácia de resultados das políticas públicas.

O perfil fragmentário dos gabinetes ministeriais fez surgir, ampliou, acentuou e fortaleceu a feudalização da máquina pública em todos os níveis e naturalizou perante os partidos o mecanismo de distribuição de cargos dos altos escalões, em troca de apoio aos projetos do governo. Essa forma de operar as políticas públicas implica, de um lado, a formação de um modelo perverso em que as ações governamentais se tornam cada vez menos republicanas e, de outro, um modelo cada vez mais ministerial e partidário.

Portanto, tudo que se preconiza hoje no mundo, referindo-se à atuação do Estado na busca por integrar o maior número de ações e entender os problemas segundo a ótica da transversalidade, tem escassa efetividade prática no Brasil, prevalecendo apenas no discurso. Por fim, constatamos que o caráter coordenativo das políticas públicas tem um limite claro, dado pela arquitetura política elaborada para garantir a governabilidade do país. 


\section{REFERÊNCIAS}

ABRANCHES, S. H. H. Presidencialismo de coalizão: o dilema institucional brasileiro. Revista Dados, v. 31, n. 1, p. 5-34, 1988.

ABRUCIO, F. L. A coordenação federativa no Brasil: a experiência do período FHC e os desafios do governo Lula. Revista de Sociologia Política, v. 24, p. 41-67, 2005.

BAKVIS, H.; JUILLET, L. O desafio horizontal: ministérios setoriais, órgãos centrais e liderança. Brasília (DF): Enap, 2004.

CARREIRÃO, Y. S.; NASCIMENTO, F. P. As coligações nas eleições para o Senado brasileiro. In: KRAUSE, S.; DANTAS, H.; MIGUEL, L. F. Coligações partidárias na nova democracia brasileira. São Paulo: Ed. Unesp, 2010. 75-104 p.

FERRAZ, A. S. Privatização e processo decisório. Revista Dados, v. 52, n. 2, p. 425-469, 2009.

GRAU, N. C. La intersectorialidad em el gobierno y gestión de la política social. In: CONGRESO INTERNACIONAL DEL CLAD SOBRE LA REFORMA DEL ESTADO Y DE LA ADMINISTRACIÓN PÚBLICA, 10., 2005, Santiago. Anais... Santiago: CLAD, 2005. 1-52 p.

INOJOSA, R. M. Sinergia em políticas e serviços públicos: desenvolvimento social com intersetorialidade. Cadernos Fundap, n. 22, p. 102-110, 2001.

INSTITUTO DE PESQUISA ECONÔMICA APLICADA - IPEA. Brasil em desenvolvimento: Estado, planejamento e políticas públicas. Brasília (DF): IPEA, 2010.

KINGDON, J. Juntando as coisas. In: SARAVIA, E.; FERRAREZI, E. (Org.). Políticas públicas: coletânea. Brasília (DF): Enap, 2007. 225-246 p.

KRAUSE, S.; GODOI, P. P. Coligações eleitorais para os executivos estaduais: padrões e tendências. In: KRAUSE, S.; DANTAS, H.; MIGUEL, L. F. Coligações partidárias na nova democracia brasileira. São Paulo: Ed. Unesp, 2010. 41-90 p.
LANDÉ, C. The dyadic basis of clientelism. In: SCHMIDT, S. W. (Ed.). Friends, followers and factions: a reader in political clientelism. Berkeley: University of California, 1983. 13-32 p.

LIMONGI, F. Presidencialismo e governo de coalizão. In: AVRITZER, L.; ANASTASIA, F. Reforma política no Brasil. Belo Horizonte: Ed. UFMG, 2006. 237-268 p.

MACHADO, A. Coligações eleitorais minimamente vitoriosas no Presidencialismo: realidade ou ficção? O caso do Brasil. In: KRAUSE, S.; DANTAS, H.; MIGUEL, L. F. Coligações partidárias na nova democracia brasileira. São Paulo: Ed. Unesp, 2010. 217-244 p.

MARSH, D. La convergencia entre las teorias del Estado. In: MARSH, D.; STOKER, G. (Org.). Teoria y métodos de la ciencia política. Madrid: Alianza, 1997. 273-292 p.

MELO, M. A. Governance e reforma do Estado: o paradigma agente x principal. Revista do Serviço Público, v. 120, n. 1, p. 67-82, 1996.

MENEGUELLO, R. Partidos e governos no Brasil contemporâneo (1985-1997). São Paulo: Paz e Terra, 1998.

MINISTÉRIO DA INTEGRAÇÃO NACIONAL-MI. Programa de Promoção da Sustentabilidade de Espaços Sub-regionais. Brasília (DF): MI 2010.

NUNES, E. O. A gramática política do Brasil: clientelismo e insulamento burocrático. Rio de Janeiro: Jorge Zahar, 1997.

PEIXOTO, V. M. Coligações eleitorais nos municípios brasileiros: competição e estratégia. In: KRAUSE, S.; DANTAS, H.; MIGUEL, L. F. Coligações partidárias na nova democracia brasileira. São Paulo: Ed. Unesp, 2010. 277-300 p.

REIS, F. W. Governabilidade, instituições e partidos. Novos Estudos Cebrap, n. 41, p. 40-59, 1995.

João Mendes da Rocha Neto

Graduado em Geografia/Bacharelado pela Universidade Federal do Rio Grande do Norte; Mestre e Doutor em Administração Pública pela Universidade Federal do Rio Grande do Norte; Professor do Programa de Pós-graduação em Administração da Universidade de Brasília. E-mail: jmdrn@uol.com.br

Djalma Freire Borges

Graduado em Direito pela Universidade Federal de Pernambuco; Especialista em Economia pela Escola Superior de Economia de Praga/Tchecoslováquia; Mestre em Administração pela Universidade Federal da Paraíba; Doutor em Administração de Empresas pela Fundação Getulio Vargas - SP; Professor do Programa de Pós-graduação em Administração da Universidade Federal do Rio Grande do Norte. E-mail: dfb@ digimail.com 